\title{
Cat and Mouse: HIV Transcription in Latency, Immune Evasion and Cure/Remission Strategies
}

\author{
Aurélie Delannoy@, Mikaël Poirier and Brendan Bell * (1) \\ Département de Microbiologie et Infectiologie, Faculté de Médecine et des Sciences de la Santé and Centre de \\ recherche du CHUS, Université de Sherbrooke, Sherbrooke, QC J1E 4K8, Canada; \\ Aurelie.Delannoy@USherbrooke.ca (A.D.); Mikael.Poirier@USherbrooke.ca (M.P.) \\ * Correspondence: Brendan.Bell@USherbrooke.ca; Tel.: +001-819-821-8000 (ext. 75327)
}

Received: 16 January 2019; Accepted: 13 March 2019; Published: 18 March 2019

\begin{abstract}
There is broad scientific and societal consensus that finding a cure for HIV infection must be pursued. The major barrier to achieving a cure for HIV / AIDS is the capacity of the HIV virus to avoid both immune surveillance and current antiretroviral therapy (ART) by rapidly establishing latently infected cell populations, termed latent reservoirs. Here, we provide an overview of the rapidly evolving field of HIV cure/remission research, highlighting recent progress and ongoing challenges in the understanding of HIV reservoirs, the role of HIV transcription in latency and immune evasion. We review the major approaches towards a cure that are currently being explored and further argue that small molecules that inhibit HIV transcription, and therefore uncouple HIV gene expression from signals sent by the host immune response, might be a particularly promising approach to attain a cure or remission. We emphasize that a better understanding of the game of "cat and mouse" between the host immune system and the HIV virus is a crucial knowledge gap to be filled in both cure and vaccine research.
\end{abstract}

Keywords: HIV; latency; transcription; cure; remission; immune evasion; immunotherapy

\section{Introduction}

Human immunodeficiency virus (HIV-1) virus was identified in 1983 as the cause of the acquired immunodeficiency syndrome (AIDS) [1]. The discovery of HIV and its subsequent characterization made possible the development of the antiretroviral therapy (ART) currently used clinically to treat HIV infected people. ART is a combination of drugs that targets the replication of the virus and decreases HIV viremia durably in patients, curtails transmission and extends life. However, the disease is far from being under control. In 2017, a report of UNAIDS estimated that 77.3 million people had been infected worldwide since the start of the epidemy, and that $59 \%$ of the 36.9 million people who are still living with the virus had access to the treatment [2]. This constitutes a significant progress since only half of them had access to a treatment in 2010, but there is still a lot to do to achieve the 90-90-90 targets by 2020 ( $90 \%$ of people living with HIV know their status, $90 \%$ of them are on HIV treatment, among whom $90 \%$ achieve viral suppression). Moreover, even in regions where this goal was almost reached in 2016 [3], there is still a high need for new therapeutic approaches that could definitely cure the disease. The burdensome side effects of ART and the possible emergence of resistance to available therapy are two reasons to pursue a cure $[4,5]$.

\section{Latency and the Latent Reservoirs}

The main obstacle to a cure resides in the so-called latent reservoirs, generally defined as cells bearing full length HIV-1 proviruses that are replication competent but transcriptionally inactive. These 
cell populations are not targeted by ART, either because of their latent status or because they cannot be reached by the drugs (reviewed in [6,7]) but can still be reactivated upon treatment interruption [8].

\subsection{The Latent Reservoir Is Constituted of Several Subsets of Immune Cells with Specific Features}

The latent reservoir is established very early upon HIV infection and although treatment with ART during the acute phase can reduce the size of the reservoir, it is not sufficient to prevent the establishment of a pool of latently infected cells $[9,10]$. It has often been assumed that viral latency occurs when recently infected activated CD4+ T cells revert to a memory state [6]. However, accumulating evidence suggests that the latent reservoir is composed of a more diverse population and that its establishment and dissemination are regulated by more complex mechanisms.

\subsubsection{The Different Populations of the Reservoir}

The largest fraction of the reservoir is constituted by memory T cells (reviewed in [11]) These memory $\mathrm{T}$ cells can be divided into several subsets with distinct features (Reviewed in [11,12]). T stem cell memory $\left(\mathrm{T}_{\mathrm{SCM}}\right)$ are the least differentiated subset and are the precursors of central memory $\left(\mathrm{T}_{\mathrm{CM}}\right)$, effector memory $\left(\mathrm{T}_{\mathrm{EM}}\right)$ and terminally differentiated $\mathrm{T}$ cells $\left(\mathrm{T}_{\mathrm{TD}}\right)$. The transitional memory $\left(\mathrm{T}_{\mathrm{TM}}\right)$ are an intermediate between $\mathrm{T}_{\mathrm{CM}}$ and $\mathrm{T}_{\mathrm{EM}}$ and effector cells. Migratory memory ( $\mathrm{T}_{\mathrm{MM}}$ ) cells circulate between the peripheral blood compartment and the tissues where another subset, the tissue resident memory $\left(T_{R M}\right)$, stay more permanently (reviewed in [12]). Other $T$ cell types are involved in the maintenance of the reservoirs, e.g., the naïve $T$ cells $\left(T_{N A}\right)$, the precursors of $T_{C M}$, which are permissive to HIV but at low frequencies $[13,14]$. All these subsets contribute to the reservoir but to different extents (reviewed in [12]), and this contribution is mostly affected by the maturation and differentiation state of the cell [11]. It was first shown that, among the $\mathrm{T}$ cell population of the reservoir, central memory $\mathrm{T}$ cells, was the most prevalent subset $[6,13,15]$, while the $\mathrm{T}_{\mathrm{TD}}$ was the least prevalent one [6]. This is due to their life span, which is longer than the one of the effector or terminally differentiated subsets [16], and their IL-7 driven homeostatic proliferation [17]. More recently, $\mathrm{T}_{\mathrm{SCM}}$ were shown to persist even longer, with an average life span of 277 month (vs. 144 for central memory T cells) and a more pronounced proliferation capacity $[18,19]$. These features may explain the increased overrepresentation of this subset in the total reservoir compared to central memory $\mathrm{T}$ cells along the duration of ART $[18,19]$. The undifferentiated state also appears to correlate with the permissiveness to the virus. $\mathrm{T}_{\mathrm{SCM}}$ have been shown to be highly permissive since the proportion of cells containing HIV-1 DNA is higher in this subset than in $\mathrm{T}_{\mathrm{NA}}, \mathrm{T}_{\mathrm{CM}}, \mathrm{T}_{\mathrm{EM}}$ and $\mathrm{T}_{\mathrm{TD}}$ [19].

The above findings are in accordance with the observation that Th17 polarized cells are more susceptible to HIV-1 infection [20]. Interestingly, these cells have stem-cell-like properties since they have a long life span, replicate in an homeostatic manner and have a wide developmental plasticity [21,22]. In addition, a subset of the polarized Th1/Th17 CD4+ effector T cells, containing replication competent HIV-1, has been shown to survive for several years upon ART [23]. A recent study by Wacleche et al. demonstrated that a restricted subpopulation of Th17 cells expressing the marker CCR6, but not CCR4 or CXCR3, was predominant in the blood and the lymph nodes of ART treated individuals compared to the other Th17 subsets [24]. Interestingly, this specific subset shows features that are characteristic of follicular T helper cells (Tfh), and thus could be an intermediate between Th17 and Tfh. Follicular T helper cells are T helper cells that are located in the lymph nodes and they have also been identified as a possible component of the reservoir since they are highly permissive to the virus and are a major site of HIV replication in untreated patients [25]. Moreover, a subpopulation of circulating $\mathrm{T}$ cells that share properties with $\mathrm{Tfh}$, subsequently named peripheral follicular T helper cells (pTfh), have been identified recently [26]. The contribution of Tfh and pTfh to the reservoir is still unclear and under investigation, but a study showed that HIV-1 DNA was detected in pTfh of the majority of the patients [23]. These cells even represent $20 \%$ of total memory T cells, are more permissive to HIV-1 infection and carry a higher proportion of replication competent proviruses than other $\mathrm{T}_{\mathrm{CM}}$ [26-28]. Garcia and coworkers have demonstrated that the largest difference 
in reservoir size between elite controllers and patients treated with successful ART was observed in pTfh subset. This finding suggests that pTfh subpopulation may be a key actor in the maintenance of the reservoir, likely because of its ability to support high levels of HIV replication [29].

Finally, an atypical subset of the T cell lineage, the $\gamma \delta \mathrm{T}$ cells, that have the ability to recognize bacterial pathogens but can also display a memory phenotype, have been shown to carry latent HIV-1 proviruses and could then be part of the reservoir [30].

This review focuses on CD4+ $\mathrm{T}$ cells because they constitute the most extensively studied reservoir [31,32]. However, it is worth mentioning that other populations of the immune system, such as monocytes/macrophages, natural killer or dendritic cells can also contribute to the reservoir in a potentially significant manner. Monocytes/macrophages express the CD4 receptor, although at lower levels compared to CD4+ T cells and, therefore, are permissive to HIV-1 infection [33]. Moreover, macrophages are resistant to the cytopathic effects of the virus and show long lifespans [34,35]. Therefore, the macrophages might contribute significantly to the reservoir by sustaining productive infection and facilitating new infection of CD4+ T cells [36,37]. The macrophages are also involved in the infection of the central nervous system since infected macrophages have been detected in the brain of long term ART treated individuals [38]. On the other hand, mature dendritic cells are potently resistant to HIV-1 infection, notably through the high expression of the host restriction factor SamHD1, so only a small fraction of the dendritic cell population is efficiently infected by HIV [36,37]. However, dendritic cells retain viral particles at their surface that can remain infectious for several months [39] and may contribute to the new infection of CD4+ T cells [40].

\subsubsection{The Different Compartments of the Reservoir}

The cells that constitute the reservoir are present in different compartments, including the peripheral blood, the central nervous system, the lymph nodes, the gut associated lymphoid tissue (GALT), and, more generally, tissues that contain HIV-infected cells [33,41-43]. The peripheral blood compartment is the best characterized and the most extensively studied for feasibility reasons. However, increasing evidence suggests that the other compartments may also contribute to the HIV-1 reservoirs, especially the GALT [43]. The GALT is the largest lymphoid tissue in the body and shows a 2-4-fold increase in the proportion of cells containing HIV-1 DNA than the peripheral blood compartment [43]. Two subsets of memory $T$ cells have been shown to contribute specifically in the compartments: the tissue resident memory $\mathrm{T}$ cells $\left(\mathrm{T}_{\mathrm{RM}}\right)$, which stay in a specific region of a tissue, and the migratory memory $\mathrm{T}$ cells $\left(\mathrm{T}_{\mathrm{MM}}\right)$ that can get back to the blood circulation $[41,44,45]$. Together with the macrophages, these $\mathrm{T}_{\mathrm{MM}}$, can migrate between the blood and the tissues and might participate in the dissemination of the virus and the establishment of reservoirs in the different compartments $[43,46]$.

The lymph nodes represent a challenge for an HIV cure for three main reasons. Firstly, they are home to follicular $\mathrm{T}$ helper cells ( $\mathrm{Tfh}$ ), a subset of $\mathrm{T}_{\mathrm{CM}}$ that are the major contributor to latency persistence in ART-treated or controller patients [47,48]. Secondly, they promote the infection of those Tfh by keeping them in close proximity with the follicular dendritic cells within structures called B-cell follicles [25,49]. Thirdly, they have been shown to be less accessible to drugs than blood cells [50]. The recent identification of $\mathrm{pTfh}$ might help further characterize the Tfh reservoir.

Two other HIV sanctuaries are the genital tract and the brain $[38,51]$. In the testes, the reservoir is mainly constituted of CD4+ resting T cells, whereas in the brain most of the latently infected cells are macrophages $[38,51]$. Both present the same obstacle: a tight barrier that separates them from the blood stream and can impair the distribution of ART into these organs [50]. A recent study by Huang et al. has shed the light on the mechanisms that control the selective permeability of the blood-testis barrier to certain molecules of ART in human biopsies [52]. The study characterized the expression and the localization of ABC and SLC drug transporters, as well as metabolic enzymes and nuclear receptors previously shown to be involved in antiretroviral drug penetration in biopsies of ART treated HIV infected patients and uninfected individuals. They also showed that drug penetration was 
highly variable from one drug to the other. For example, nucleoside/nucleotide reverse transcriptase inhibitors (NRTIs) showed levels comparable to plasma, whereas protease inhibitors had diverse penetration with darunavir concentrations falling below therapeutic values.

\subsubsection{Establishment and Maintenance of the Reservoir}

It has long been thought that memory $\mathrm{T}$ cells had a long life span (up to several years), mostly based on the observation that the immune memory itself can last for years (reviewed in $[53,54]$ ). However, data now support the notion that the life span of memory T cells is shorter (from six months to one year) and imply that the pool of latently infected memory $\mathrm{T}$ cells is maintained by mechanisms other than the simple longevity of latent $\mathrm{T}$ cell reservoirs (reviewed in $[6,53,55]$ ). Some of these subsets are maintained by proliferation, since $\mathrm{T}_{\mathrm{CM}}$ and $\mathrm{T}_{\mathrm{TM}}$ cells expressing higher levels of proliferation markers ki67 and PD1 are enriched for HIV-1 provirus in ART treated individuals [6]. This hypothesis is also supported by the homogeneity of the viral DNA sequences in the reservoir of patients on ART treatment [56-58]. The recent observation that CD4+ T cells can undergo homeostatic proliferation without necessarily reactivating viral expression [59], and that latently infected cells might need more than a single round of stimulation to be reactivated [60-62] supports this notion. Memory T cells are permissive, albeit at low frequency, to HIV infection $[28,63]$ and the virus can be transmitted efficiently by cell-to-cell contact, either between $\mathrm{T}$ cell and antigen presenting cells (e.g., macrophages or dendritic cells) or even between two T cells $[55,64,65]$. A recent study by Agosto et al. showed that activated HIV infected CD4+ T cells have the ability to infect resting CD4+ T cells by cell-to-cell contact and that this mode of infection generated latent viruses with a decreased reactivation ability compared to other modes of infection [55]. These observations suggest that viral expression might be less stochastic and more tightly regulated than it was assumed previously.

\subsection{The Establishment and Maintenance of the Latency Involves the Hijacking of Different Cellular Processes}

The quantification and characterization of the reservoir has long been a challenge due to the weak proportion of replication competent proviruses among the total population of HIV-1 infected cells. To date, the quantification of the reservoir has mainly used two techniques: qPCR targeting the viral DNA and quantitative viral outgrowth assay (qVOA) [66]. The quantification by qPCR is very sensitive but has been shown to overestimate the reservoir [61,67-69]. On the other hand, qVOA might underestimate the size of the reservoir since some of the latent integrated proviruses require several rounds of stimulation before reactivation [60-62]. The recent development of new single cell-based methods should provide more accurate measurements of the latent reservoir. One new technique called flow-FISH combines the detection of GagPol mRNA by in Situ hybridization with antibody staining of Gag protein and allows the quantification and characterization of the reservoir in clinical samples [70]. Another example is the use of a dual-fluorescence based reporter vector combined to cell sorting on the base of their ability to express the virus and OMICS analysis of the different subsets shed the light on the mechanisms governing HIV latency [71-73]. The identification of 70 potential biomarkers of latency by an integrative analysis of mRNA expression and epigenetic marks has also facilitated a better characterization of latent pools [74].

\subsubsection{HIV Plays a Game of Cat and Mouse}

Several lines of evidence point toward HIV latency as an evolutionarily acquired advantage to escape the immune system. HIV can also manipulate several components of immune signaling, presumably to its own advantage. An example is the PD1 negative regulator of the immune response $[75,76]$ that plays a role in HIV infection and latency. It has been shown that HIV-1 preferentially infects $\mathrm{T}$ cells that express high levels of PD1 [6,77] and that this protein is found upregulated at the surface of both HIV-specific CD8+ and CD4+ T cells [78-81]. Moreover, a recent study by Evans et al. has shown that the expression of PD1 and other immune checkpoints favors HIV latency in resting CD4+ T cells and that the use of an antibody targeting PD1 can reactivate HIV-1 
expression in an individual under ART [82]. Finally, it has been demonstrated that another way for HIV to neutralize the immune system is to target preferentially HIV-specific CD4+ T cells [83].

\subsubsection{The Hypermutagenicity of the Virus Favors the Latency}

It is estimated that only $5 \%$ of latent HIV proviruses are replication competent $[68,84]$. The remaining $95 \%$ were shown to carry deleterious modifications of their genome such as large deletions or multiple mutations [72]. The mutation rate of HIV-1 has been evaluated at $4.1 \times 10^{3}$ per base per cell in vivo, the highest of any biological entity [85], and is mainly due to the error-prone HIV-1 reverse transcriptase as well as G-to-A APOBEC3G induced hypermutation [86,87]. APOBEC proteins are restriction factors involved in innate immunity with a cytidine deaminase activity and are inhibited by the viral accessory protein Vif [88]. This high mutation rate is a solid advantage for the rapid evolution and adaptability of the virus and could then promote HIV latency under the selective pressure imposed by ART treatment [89]. Evidence of the impact of mutations on latency has been provided by a recent study using a dual fluorescence reporter vector to identify seven reactivatable latently infected clones, among which five carried mutations. Interestingly, two of these clones had mutations in the trans-activation response element (TAR), disrupting the interaction with the viral trans-activator of transcription Tat [72]. Mutations in the viral genome occur most likely before initiation of ART, as suggested by the decay in genetic diversity of the virus observed after ART initiation and the capacity of latently infected CD4+ T cells to expand clonally $[90,91]$.

\subsubsection{The Site of Integration and the Epigenetic Marks Play a Role in HIV Expression}

The site of integration of the HIV provirus into its host genome seems to play an important role for HIV expression and thus for latency regulation. Large scale sequencing studies performed in several model cell lines have identified millions of possible integration sites throughout the genome [92,93] and even if a consensus sequence has been identified, it modestly impacts the choice of the integration site in vitro [94]. However, the virus targets specifically regions of the genome that are actively transcribed (reviewed in $[95,96]$ ) and carry epigenetic marks associated with an open chromatin and active transcription such as CpG islands, acetylation of H3K9 or trimethylation of H3K36 [97-99]. HIV has also been shown to preferentially integrate into genes that undergo alternative splicing, without any preference for exons or introns in HEK293T [92]. This choice can be explained by the molecular mechanisms that underlie the integration. HIV enters the host cell nucleus as a nucleoprotein complex (called the pre-integration complex) composed of the full length viral DNA genome, viral proteins such as Vpr or the integrase and host cell factors. The integrase then interacts with the lens epithelium-derived growth factor (LEDGF) and the cleavage and polyadenylation specificity factor 6 (CPSF6). LEDGF binds trimethylated H3K36, an epigenetic mark associated with active transcription [100] as well as splicing factors [92], and CPSF6 is also involved in splicing [97]. The physical interactions between the preintegration complex and factors involved in splicing explains the preference for integration in highly expressed and spliced genes. Finally, the nuclear organization might also have an important role in the choice of the integration site. Indeed, pre-integration complexes have been detected in areas of decondensed chromatin at the periphery of the nucleus [99], and HIV recurrent integration genes (RIGs) were found clustered in regions of the chromosomes that are close to the nuclear pore complexes (NPC) [98].

Taken together, the above evidence points towards an important role of the genomic context in the expression pattern of the integrated provirus and it is tempting to assume that the site of integration could predict the latency status. However, the data available to date do not unambiguously support a simple determinant role for the genomic integration site on latency. For example, it has been observed that the integration of HIV in alphoid repeats or into gene deserts might favor latency $[101,102]$ and that viral transcription was dependent on the orientation of the integration and the transcription rate of the host gene in primary and model cell lines $[103,104]$. Moreover, a recent study using a dual fluorescent reporter system in primary $\mathrm{CD} 4+\mathrm{T}$ cells showed that the reactivation potential of latently 
infected cells correlates with gene transcription and that non-reactivable proviruses were integrated to a higher extent in heterochromatic regions associated with the lamins [73]. On the other hand, a meta-analysis performed in five model cell lines failed to find a correlation between latency and epigenetic marks, the orientation of integration or the presence of alphoid repeats [101]. Another model was proposed by Weinberger et al., based on mathematical modeling, wherein the latency phenotype would be primarily determined by the stochastic expression of the Tat protein in addition to the genomic environment, cell signals or the cell cycle [105].

Overall, the available data suggest that the site of integration or the chromatin status might not be the only mechanism explaining the latency establishment and/or regulation and that it would be better to target other components that are less dependent on genomic integration site or chromatin state.

\subsubsection{RNA Processing}

RNA processing includes alternative splicing, $5^{\prime}$ capping, $3^{\prime}$ end polyadenylation, RNA modification and quality control, all of which are critical for HIV protein expression.

The $9 \mathrm{~kb}$ genome of the virus encodes nine genes whose sequences partially overlap. To ensure proper gene expression, the virus hijacks the splicing system of the host cell and produces up to 70 different RNA isoforms [106]. The splicing of HIV is regulated by sequence motifs called splicing enhancers and splicing inhibitors, as well as stem loop structures on the RNA which can be bound by host cell factors of the SR and hnRNP family (reviewed in [107]). Thus, the binding of SRp75 or SRP40 and ASF/SF2 on specific enhancers promote splicing towards Vif or Nef, respectively [108,109], and SRSF10 is required for the efficient expression of Tat, Gag and Env [110]. On the other hand, hnRNP A1 and hnRNP H binding to splicing silencers prevents Tat expression [111,112]. Several lines of evidence also suggest that, during the later stages of the HIV life cycle, alternative splicing is repressed to promote the production of full-length and unspliced HIV RNA [113] and that Tat has a central role in this process. Indeed, Tat promotes HIV mRNA splicing via the phosphorylation of SF2 [113]. However, as the replication cycle progresses, Tat becomes acetylated and ends up repressing splicing through the recruitment of the splicing inhibitor p32 [113]. Other accessory proteins of HIV have been shown to regulate splicing. For example, Vpr has the ability to repress splicing [114].

Other mechanisms of RNA metabolism are also important for the viral replication. For example, Sam68 is involved in the polyadenylation of the HIV mRNA [115], hnRNP E1 regulates Rev expression through inhibition of RNA translation [116] and Rev itself is involved in mRNA translation and required for the nuclear export of unspliced RNA [117]. The RNA quality control pathway is also involved since UPF1 has been shown to favor reactivation, whereas UPF2 and SMG6 repress it [118].

Direct evidence now suggests that RNA processing impacts latency and the reactivation potential. Two recent studies using droplet digital PCR (ddPCR) to characterize patient latently infected cells have shown a defect in transcriptional regulation as well as in the splicing $[119,120]$. Moreover, a study by Golumbeanu et al. used single cell RNA sequencing to show that the reactivation potential of latently infected cells can be explained by the differential expression of 134 genes enriched for RNA metabolism related pathways such as RNA splicing, Ribosomal genes or translational regulation [121]. It has also been observed that the transcriptional activation induced by Latency reactivating agents (LRA) such as HDAC inhibitors was not necessarily correlated with protein expression in vivo [122], probably because these LRAs fail to reactivate factors required for RNA processing such as the Rev cofactor MATR3 [123].

\subsection{5. miRNAs}

MicroRNAs (miRNAs) are short single stranded oligonucleotides that specifically address the RNA-induced silencing complex (RISC) to mRNA to mediate post transcriptional gene silencing [124]. Although the impact of miRNA mediated regulation of HIV is an emerging topic, an accumulation of evidence suggests that this mechanism might be important in several ways. Several of these miRNAs have been shown to modulate HIV expression (Table S1) [125-128]. These miRNAs can 
directly target the virus, such as miR-29a and miR-125b, that target nef or the $3^{\prime} \mathrm{UTR}$ sequence respectively (Table S1) $[126,128]$. Other miRNAs can regulate HIV indirectly by targeting cellular factors. For example, miR-17/92, miR-17-5p and miR-20a downregulate the Tat co-activator PCAF and miR-29b, miR-150, miR-223 and miR-27b inhibit the expression of Cyclin T1 (Table S1) $[127,129,130]$. RNA silencing machinery inhibits HIV replication and the viral proteins Tat and Vpr inhibit RNA silencing $[129,131,132]$. The HIV-1 virus itself encodes for miRNAs that target either host cell factors, such as the anti-apoptotic protein AATF or HIV itself. Interestingly, several HIV-encoded miRNAs have been involved in HIV transcriptional regulation and act at the level of the $5^{\prime}$ LTR. MiR-M367 impairs viral expression and targets the U3 negative response element in CD4+ T cell lines (Table S1) [133]. TAR-derived miRNAs exert the same effect through the chromatin remodeling of the promoter by HDAC-1 [134]. Mir-H3, on the other hand, promotes HIV transcription when overexpressed and targets the TATA box in activated primary CD4+ T cells [135]. Cellular miRNA expression profiles can be modified upon HIV infection [136] and CD4+ T cell activation [128,137]. More importantly, it has been shown that elite controllers show higher plasma levels of several miRNAs that can reduce HIV infection in vitro [138]. Those miRNAs could then be an attractive way to detect and diagnose HIV. Similar to the endogenous targeting of HIV by miRNAs, it may be possible to exploit exogenous RNA-based strategies for HIV cure strategies. For example, shRNA and siRNA have been shown to target and efficiently silence HIV-1 expression [139-141]

\subsubsection{The Cell Cycle}

The regulation of the host cell cycle and of the viral replication are tightly linked in CD4+ $\mathrm{T}$ cells. This was first suggested by the observation that cell cycle activation is required for HIV replication [142,143]. A growing body of evidence has now identified multiple viral strategies to hijack cell cycle regulation. For example, the promotion of transcription by Tat trans-activation is dependent upon cell cycle regulation since it depends mostly on the expression and activity of cyclin $\mathrm{T} 1$ and cyclin dependent kinases. It has been shown that the downregulation of Cyclin $\mathrm{T} 1$ is required for the establishment of latency [144] and that this downregulation is mediated by the miRNAs miR-27b, miR-150 and miR-223 in resting T cells (Table S1) [127]. In addition, Cdk9 kinase activity, which is required for HIV transcription elongation, is regulated in a cell cycle dependent manner through dephosphorylation by PPM1A [145] and phosphorylation by Cdk7 [146]. The virus can also manipulate the cell cycle with the viral accessory protein Vpr which is highly conserved throughout HIV evolution [147] and mediates cell cycle arrest in G2/M phase [148,149]. This cell cycle arrest in G2/M has been associated with an increased activity of the HIV promoter in cellulo $[150,151]$ and in vivo [72]. Unexpectedly, the establishment of latency does not require the inactivation of Vpr [152] and MX1, a host cell factor known to be upregulated by Vpr [153] that was found overexpressed in five HIV-1 latently infected cell lines [74]. In addition, a recent study by Kok et al., using a dual fluorescence HIV-1 based vector, has shown that a subpopulation of latently infected lymphoblastic SUP-T1 cells was able to undergo reactivation in a cell cycle dependent manner. This observation was supported by the specific regulation, in these cells, of genes involved in cell cycle regulation, such as FosB, NEAT1, EGFR or RN7SK. Moreover, large fractions of those cells were in the S and G2 phase and reactivation of latent cells was achieved by blocking the cells in G2 phase through treatment with genistein or nocodazole [72]. These observations suggest that the persistence of the reservoir requires the dampening instead of the total suppression of the cell cycle dependent activation of viral expression. This could then allow clonal expansion without necessarily activating HIV replication and/or the resulting cell clearance by ART or the immune system. This hypothesis is further supported by the observation that homeostatic proliferation of $\mathrm{T}_{\mathrm{CM}}$ reservoir induces a partial reactivation of HIV without cell death, and thus could account for the maintenance of the reservoir [59]. 


\subsubsection{Apoptosis}

The cells that compose the latent reservoir are characterized by a long life span. This is in part due to their low proliferation rate, but several studies suggested that latency is also associated with modifications in the regulation of cell survival and apoptosis. For example, antiapoptotic factors such as Bcl-2, Mcl-1, cFlip and XIAP have been found to be overexpressed [154-156], whereas proapoptotic Bax and Fadd [157] have been found to be downregulated in latently infected T-cells. The regulation of these factors also prevents HIV expression. For example, ROS have been shown to induce HIV reactivation [158], but the overexpression of Bcl-2 protects the cells from ROS through their neutralization by elevated levels of glutathione and thioredoxin [154]. A role has also been proposed for caspases in HIV-1 reactivation [159] and a quantitative mass spectrometry-based study of latently infected CD4+ T cells showed that they express increased levels of BIRC5 (an inhibitor of Caspase 9) [160]. More recently, the ontological study of 70 markers of latency has shown the enrichment for processes involved in cell death inhibition [74].

Furthermore, it has been demonstrated that primary culture of HIV-1 latently infected $\mathrm{T}_{\mathrm{CM}}$ have longer telomeres, suggesting that reactivation of the telomerase could contribute to the longevity and clonal expansion of the reservoir [161]. It has also been shown that the reservoirs were enriched for viral integration in the genes coding for BACH2, STAT5/SB and MLK2 and that the interruption of those genes also favors the survival and clonal expansion of those cells [162,163].

\subsubsection{Autophagy}

The catabolic process autophagy contributes to HIV latency. HIV-1 regulates autophagy in a cell type dependent manner. In macrophages, virus replication is promoted by the early stages of autophagy, while viral replication is inhibited by the later stages [164,165]. In CD4+ lymphocytes, activation of autophagy limits the viral replicative potential [166] and HIV infected individuals have this process impaired when compared to viremia or elite controllers [167]. It has been shown that autophagy promotes latency in part through the p62-mediated selective degradation of Tat [166]. This degradation also occurs to the secreted pool of Tat that can be captured by bystander cells and is controlled by the transient induction of autophagy by the viral protein Env [166].

\subsubsection{Transcription is Linked to Most of the Processes Listed above}

In this review, we focus primarily on the role of transcription in latency regulation because it is the first step in the reactivation of latent HIV and has therefore received the greatest amount of attention in the study of HIV gene expression mechanisms. In the case of host gene expression, the regulation of the transcription is tightly coupled to RNA processing mechanisms (reviewed in [168]). Since the virus uses the host cell machinery for its expression, it is not surprising that many of the processes involved in latency regulation also show connections with transcription, such as the cell cycle $[72,150,151]$ or splicing $[169,170]$. A concrete example of how transcription impacts RNA processing was shown by the observation that replacing the HIV promoter by a CMV promoter modifies HIV mRNA splicing in vitro [171]. The fact that transcription is coupled to multiple downstream gene expression events is relevant in the search for drug targets that synergistically impact HIV latency by simultaneously acting on several steps in the HIV gene expression pathway.

\section{The HIV Proximal Promoter and its Cognate Transcriptions Factors}

One of the features of the HIV genome is that it contains a single promoter within the $5^{\prime}$ LTR that is alone responsible for driving viral transcription. The HIV promoter drives the expression of viral RNAs that, after transcription, undergo splicing, processing and transport to allow the translation of the 16 viral proteins needed for the production of new virions and the regulation of latency (reviewed in [172]). 
The HIV core promoter contains a TATA box DNA motif that is essential for the recruitment of the pre-initiation complex, which recruits RNA polymerase II (RNAPII) (Figure 1). Downstream of the TATA box, the HIV promoter possesses an E-box (enhancer box), which is the target of the transcription factor AP4 (activating enhancer binding protein 4) (reviewed in [173]), as well as the host cell transcription factor USF1 (upstream stimulatory factor 1) [174,175]. Upstream of the TATA box within the proximal promoter, there are binding sites allowing SP1 and NF- $\mathrm{kB}$ transcription factors to interact with the promoter and to influence activation or repression (Figure 1).

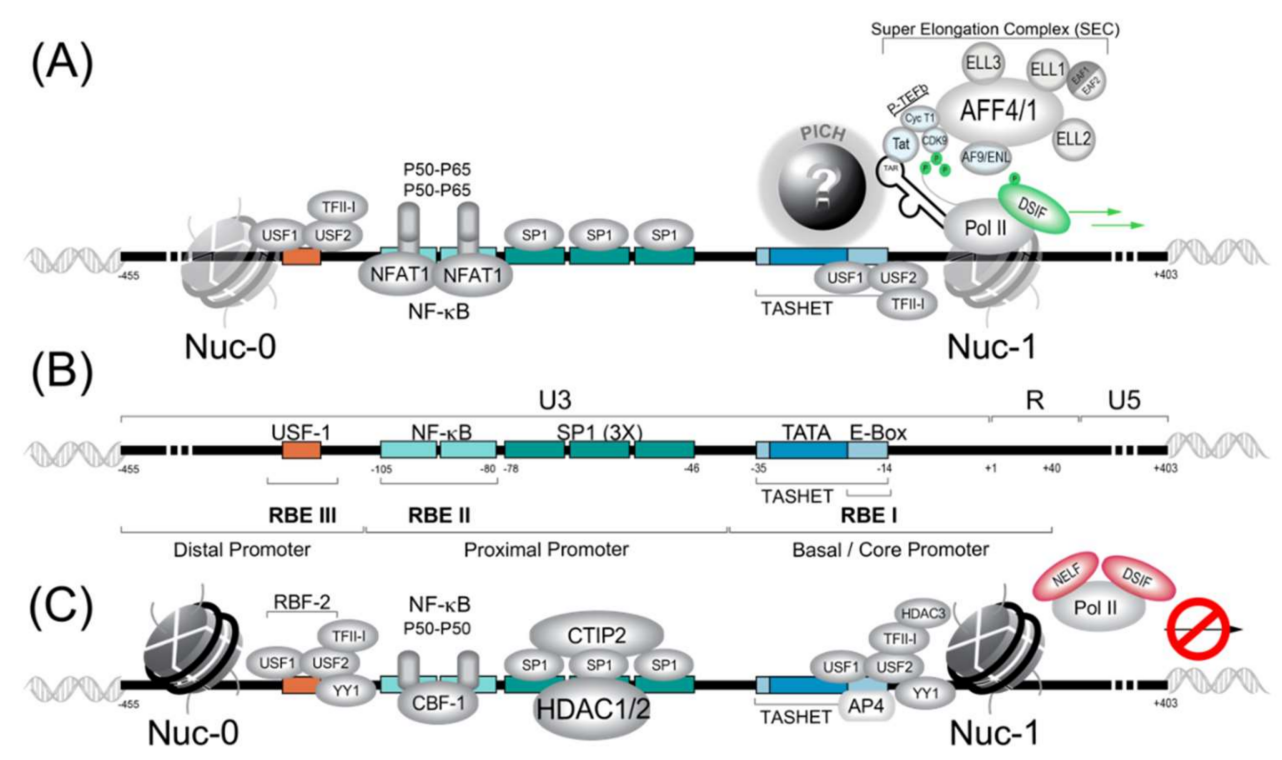

Figure 1. The human immunodeficiency virus (HIV) $5^{\prime}$ long terminal repeat (LTR) promoter region responsible for directed viral transcription is schematically represented. (A) The HIV LTR in its active state is depicted where host cell transcription factors and viral Tat activate transcription. PICH refers to pre-initiation complexes of HIV whose full identity remains an enigma. TASHET is the TATA box and adjacent sequences of HIV essential for Tat trans-activation. The super elongator complex (SEC) is shown at the right. (B) For clarity, key cis-acting DNA elements are shown in the absence of transcription factors. RBE refer to RBF-binding elements. (C) The HIV LTR is shown in a hypothetical repressed state associated with viral latency. RBF-2 refers to the Ras-responsive region binding factor 2. Note that certain transcription factors can play both positive and negative roles in HIV latency depending on the cellular context. See text for details.

Many host cell transcription factors have been found to interact with the HIV LTR (reviewed in $[176,177])$. Here, for concision, we provide a synopsis of the factors with the best-established roles in HIV transcription. Readers should bear in mind that many other factors have been implicated, and that the list of transcription factors impacting HIV latency continues to expand. We summarize the general transcription factors (GTFs), P-TEFb, NF-kB, NFAT, SP1, HDAC, AP4 and RBF-2 (USF1/USF2/TFII-I), and their roles in HIV transcription and latency. Work with cell lines has been essential for the discovery of transcription factors, as these tools provide an experimentally tractable system and suitable amounts of starting material. Thus, once transcription factors are identified, it is important to test their function in primary cells to more closely approximate the physiological situation. Work with primary cells should be facilitated by recent success with CRISPR/Cas9-based genomic editing of primary CD4+ lymphocytes [178]. Ultimately, transcription factors that bind to the HIV LTR must be verified in vivo in animal models such as humanized mice or primate models. Unfortunately, the cost of animal models has meant that studies of the HIV LTR in relevant animal models have been very limited (see Section 4.3). We also summarize the functions of the HIV auxiliary proteins Tat and Vpr in the control of HIV gene expression and latency. 


\subsection{Pre-Initiation Complex (PIC) Formation and the General Transcription Factors (GTFs)}

The formation of the pre-initiation complex (PIC) is an essential step leading to the recruitment of RNAPII at the core promoters of all class II genes. The PIC is formed by the stepwise assembly of a large complex composed of general factors of transcription (GTFs), including TFIIA, TFIIB, TFIID, TFIIE, TFIIF, TFIIH, the mediator complex and the RNAPII complex itself $[179,180]$. The first step in PIC formation is the recognition of the TATA box region by the TATA binding protein (TBP). TBP recognizes the TATA $(\mathrm{A} / \mathrm{T})(\mathrm{A} / \mathrm{T}) \mathrm{A}(\mathrm{A} / \mathrm{T})(\mathrm{A} / \mathrm{G})$ specific sequence in the minor groove of the DNA located at approximately -30 of the transcription start site (TSS) (reviewed in $[180,181]$ ). Similar to canonical promoters, activation of the HIV requires the recruitment of TBP, although the recruitment of TBP is not sufficient for activation of the HIV LTR by the viral trans-activating protein Tat [182]. In the case of the HIV promoter, the TATA box has been shown to be recognized by TBP as an atypical "CATA" box sequence [183]. In typical promoters, TBP binds to the minor groove of the TATA box, inducing a DNA kink of $90^{\circ}$. The DNA-protein interaction is stabilized by the TFIIA protein following recruitment of TFIIB. These functions of TFIIA and TFIIB are thought to act on the HIV promoter, although unlike cellular promoters TFIIA and TFIIB function appears to be modulated by the viral Tat on the HIV promoter $[184,185]$. The HIV promoter can contact TFIIB, although it does not contain a consensus TFIIB recognition element (BRE) [186]. The TFIIF subunit RAP74 is required for Tat-activated HIV transcription and can compete with HIV Tat for binding to RNA polymerase II C-terminal domain (CTD) phosphatase FCP1 $[187,188]$. The general transcription factor TFIIH is required for HIV transcriptional activation [189], and the recruitment of TFIIH is important for the reactivation of latent HIV [190]. It is therefore clear that the formation of PIC upon the HIV LTR requires the majority of the canonical GTFs, and that the function of several PIC components can be modulated by HIV Tat.

Although many canonical GTFs are required for PIC formation upon the HIV LTR, PIC formation is distinct from most cellular promoters, and these differences are important for the development of therapeutic molecules to selectively control HIV latency. For example, during canonical PIC formation, TBP is recruited to the promoter within a complex of 15 TBP-associated factors (TAFs) (reviewed in [191]). In contrast, a 2005 study suggested that PIC recruitment to the HIV promoter occurs with significantly less TAF occupancy than that observed at typical cellular promoters [192]. In fact, observations that the TATA box region of the HIV was specifically required for the trans-activation of the viral Tat protein (see Section 3.2.1) sparked the hypothesis that functionally specialized PIC, distinct from canonical PIC, might form upon the HIV LTR (reviewed in $[173,193]$ ). More recently, it was shown that an element within the core promoter region ( -35 to -14$)$ termed TASHET (TATA box and adjacent sequences of HIV essential for Tat trans-activation) is essential for the HIV LTR's response to Tat (reviewed in [173]). Moreover, the specific capacity of TASHET to confer Tat-responsive transcription of the HIV viral promoter was shown to depend on CTGC DNA motifs flanking the HIV TATA box. Although it is now clear that the HIV core promoter is specifically recognized by host cell complex termed the pre-initiation complex of HIV (PICH), the identity of the proteins involved remains a mystery (Figure 1A). Since these complexes could represent new drug targets for HIV cure strategies, their identification is of high strategic value, as discussed in detail elsewhere (reviewed in [173]).

\subsubsection{SK Complex (P-TEFb)}

During the initiation of transcription by RNAPII, the enzyme will be bound by the transcription factors NELF (Negative elongation factor) and DISF (DRB sensitivity-inducing factor), which will pause the transcription initiation [194,195] (Figure 2). To allow the paused polymerase to elongate, the 7SK complex, which is abundant in cells, plays a crucial role. The 7SK complex is a small nuclear ribonucleoprotein (snRNP) composed of a snRNA (small nuclear RNA) and the P-TEFb transcription factor itself is composed of a cyclin dependent kinase (CDK9) and cyclin T1. In addition, the proteins HEXIM1 and HEXIM2 will sequester a large part of CDK9 and inhibit its catalytic activity. The complex is stabilized by MePCE and LARP7 proteins (Figure 2) [196]. The 7SK complex also contains members 
of the so-called super elongator complex (SEC) including AFF4/MCEF, ENL/AF9 and ELL2 that also impact HIV transcription [197].

(A)

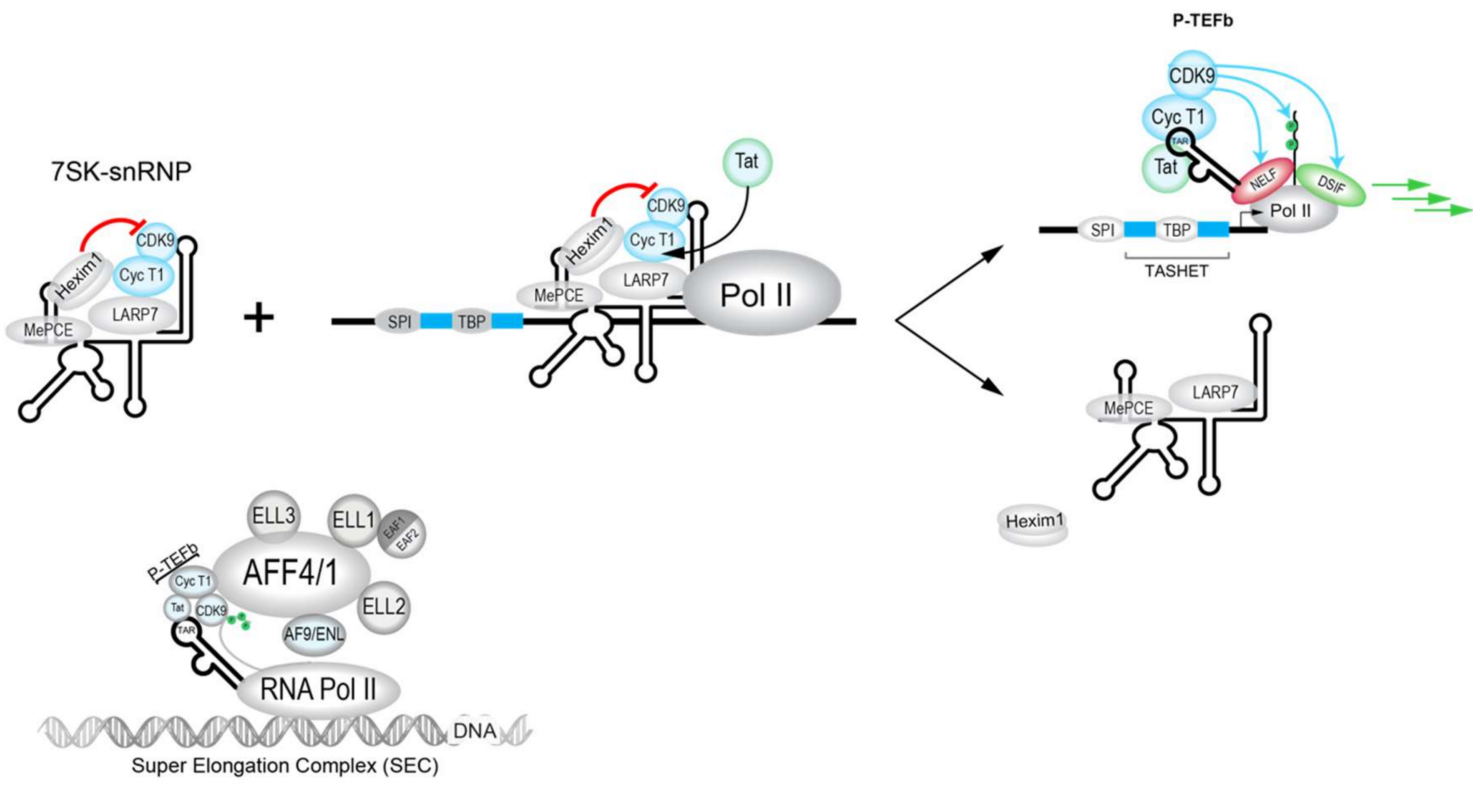

Figure 2. The role of the 7SK-snRNP/Tat/TAR in the activation of the HIV LTR is schematized. (A) The inactive HEXIM1-bound form of the 7SK-snRNP complex (left) forms upon the HIV LTR in its inactive state (middle). The HIV Tat trans-activator binds to Cyclin T1 to favor the recruitment of the active P-TEFb upon the HIV LTR (right top) and the release of an inactive form of 7SK-snRNP that lacks HEXIM1 (right bottom). Active P-TEFb phosphorylates the CTD of Pol II and other elongation factors to promote elongation of transcription. (B) A more detailed schematic view of Tat during activation of the HIV LTR in association with the super elongator complex (SEC). Tat plays a crucial role in the reactivation of HIV from latency and its action can be mimicked by several latency reversing agents (LRAs), such as JQ1.

The dynamic association between snRNA 7SK and P-TEFb is also influenced by proteins such as bromodomain containing protein 4 (BRD4). BRD4 is key interaction partner for P-TEFb and can act to inhibit Tat trans-activation at the HIV LTR. In fact, BRD4 has been targeted pharmacologically by inhibitory molecules such as JQ1 [198-200] and MMQO [201] to antagonize BRD4 repression for the activation of HIV transcription (see Table 1). The chromatin regulatory protein HMGA1 also negatively modulates HIV transcription and can bind to both 7SK RNA [202] and TAR RNA [203]. Interestingly, the expression of TAR RNA alone can influence the expression of host cell 7SK-dependent mRNAs, implying potential reciprocal interactions between HIV 7SK complexes and HIV [194] that could influence viral latency. Ultimately, modulators of $\mathrm{P}-\mathrm{TEFb}$ activity will impact its major roles the activation of processive HIV transcriptional elongation. These functions include the CDK9-dependent phosphorylation of NELF (negative elongation factor) and DSIF (DRB sensitivity-inducing factor), as well as in the phosphorylation of the carboxy terminal domain (CTD) of RNAPII (Figure 2) (reviewed in [197]).

HIV Tat recruits P-TEFb in association with the super elongator complex (SEC) to enhance RNAPII elongation. SEC complexes were found to contain either AFF4 (formerly Mcef1) or AFF1, in addition to AF9, ENL and ELL proteins (Figures 1 and 2B) [204-206]. SEC is built upon a flexible scaffold of AFF4 or AFF1, with P-TEFb (Cycline T1 and CDK9), ELL family proteins (ELL1, ELL2, and ELL3), AF9, ENL, and EAF family proteins (EAF1 and EAF2) that can interact with HIV Tat (Figure 2B) [205-208]. The recruitment of SEC to chromatin-bound RNAPII can be facilitated via interactions with the PAF1 protein within the human Polymerase-Associated Factor complex (PAFc) [209]. As more detailed structural information on the SEC complex becomes available [207,210,211], the targeting of SEC components to therapeutically modulate HIV transcription should become more feasible. 
CRISPR-based functional studies suggest that ELL2 and AFF1 play key roles in HIV latency [212]. The targeting of SEC was shown by recent studies that have identified a chalcone derivative termed Amt-87 as a small molecule activator of latent HIV that acts by favoring the release of active P-TEFb from the 7SK snRNP [213]. Moreover, AFF4 fragments have been shown to inhibit HIV transcription in cultured cells [214], suggesting the possibility that targets within SEC could be used to shut down latent HIV for a functional cure (see Section 4.5).

In addition to their essential role in HIV transcriptional control, SEC complexes play a broad role in cellular gene expression. For example, transcriptomic studies in murine embryonic stem cells showed a role for SEC components at promoters with paused RNAPII, but also at certain unpaused promoters [215]. Interestingly, the Hox family of developmental transcription factors were found to be cellular targets for regulation by SEC, and their deregulation may underpin mixed lineage leukemia (MLL) driven by fusion proteins resulting from translocation of MLL to SEC genes such as AFF1, AFF4, ENL, and AF9 [215]. Mechanistically, SEC can be recruited to promoters via interactions with the mediator subunit MED26 [216] and components of the general transcription factor TFIID (notably TAF6) [217]. SEC complexes are intensively studied because of their role in HIV transcription and latency, but also due to their roles in other disease states including leukemia [218] and adenoviral replication [219]. There are currently three known SEC complexes that include SEC, the most well-studied complex, that acts upon the HIV promoter, as well as SEC-L2 and SEC-L3 [220]. These distinct SEC complexes contain different AFF family member scaffold proteins: AFF4/AFF1 for SEC, AFF2 for SEC-L2 and AFF3 for SEC-L3 [220]. Distinct SEC can differentially control elongation of genes, for example at the HSP70 promoter SEC, but not SEC-L2 or SEC-L3, is required for RNAPII release [220]. The cellular roles for SEC represent challenges for targeting this complex for an HIV cure, since it will be important to develop strategies specific to the HIV promoter avoiding off-target effects on of cellular SEC target genes.

\subsubsection{NF- $\mathrm{KB}$}

The NF- $\mathrm{B}$ motifs within the HIV promoter are among the most studied elements of the HIV LTR and are thought to play a major role in inducible HIV gene expression. The NF- $\mathrm{B}$ family of transcription factors form part of a major cell signaling pathway that controls cell survival and influences many cellular genes (for example, TRAF6, Inhibitors of Apoptosis (IAPS), and Bcl-2 family) (reviewed in [221]). The NF- $\mathrm{BB}$ family consists of five members: P50, P65, P52, c-Rel and ReIB (reviewed in [221]). The HIV-1 $5^{\prime}$ LTR of all the major subtypes possess at least two cognate NF- $\mathrm{B}$ binding sites around -104 to -80 called Core II upstream and Core I downstream separated by four nucleotides (reviewed in [222]). With the subtype C, the promoter contains 3-4 NF-kB sites.

The NF- $\mathrm{BB}$ pathway can be triggered by intracellular or extracellular stimuli that act by modulating the activation of protein kinase $C$ (PKC). PKC is a potential drug target for the shock and kill strategy to cure HIV (see Section 4.4). NF-kB-activating stimuli can include interleukin 1 (IL-1), T-cell mitogens or pro-inflammatory cytokines such as TNF $\alpha$. PKC protein will phosphorylate IKB kinase (IKK) to activate it. Upon activation, IKK phosphorylates the IкB protein in P65-P50-IкB complex. After phosphorylation, IKB will be ubiquitinylated and degraded by the proteasome, releasing P50-P65 to enter the nucleus and bind DNA. If P50-P50 dimers bind the NF- $\mathrm{BB}$ region upstream the TATA box, it can activate the HIV-1 transcription in cooperation with SP1 and other transcription factors (reviewed in [222]). In contrast, if P50-P65 is not present, the P50-P50 homodimer will bind the NF- $\mathrm{BB}$ sites and recruit CBF-1 that then recruits HDAC1 complexes to repress the promoter (reviewed in $[222,223])$. The HIV-1 promoter contains two copies of the same $10 \mathrm{pb}$ repeat consensus NF- $\kappa B$ binding sites (reviewed in [222]) that are generally, although not universally [224], conserved in HIV isolates, underlining their importance in HIV transcriptional regulation in vivo. Several small molecules that activate the NF- $\mathrm{B}$ pathway via PKC have been used to activate HIV transcription in the shock and kill HIV cure strategy, underscoring the potential clinical importance of the pathway (see Table 2). 


\subsubsection{NFAT1}

The nuclear factor of activated T cells (NFAT1) is an important transcription factor of lymphocytes in regulating the homeostasis of the immune system $[225,226]$. One of the roles of NFAT1 is to be a key to the regulation of T cell differentiation in Th1, Th2, Th17, Tfh and Treg (T regulatory cells) [225]. The structure of NFAT1 has been determined by crystallography (residues 396-678) of the Rel homology region (RHR) of the protein bound to the $\mathrm{kB}$ site [226]. The protein is a dimer when bound to the $\mathrm{kB}$ motifs in the $5^{\prime}$ LTR of HIV (GGGACTTTCC), but remains a monomer in solution, suggesting that NFAT1 must bind DNA to form its dimeric interaction [226]. NFAT1 can also bind to distinct DNA elements, for example the TGGAATTTCCA motif from the IL-8 promoter [226]. Other NFAT family members (NFAT2, NFAT3 and NFAT4) have the same dimeric structure and are predicted to be also able to interact with the HIV promoter and therefore could also play similar roles in activating HIV transcription [226].

\subsubsection{SP1}

SP1 (specificity protein 1) is important for basal activity of the HIV-1 LTR [227]. SP1 is generally considered to be constitutive in most cell types (reviewed in [223]). In the HIV-1 LTR, SP1 is localized between TATA box and NF- KB sites (reviewed in [228]). (Figure 1) In the majority of HIV-1 subtype, at least three SP1 sites are bound by three SP1 proteins and recruit co-factor COUP-TF interacting protein 2 (CTIP2) (reviewed in [223]). In certain subtype, the promoter contain 4-5 SP1 sites (reviewed in [223]). SP1 engages in multiple interactions such as with NF-kB bound to the LTR, interaction with YY1, protein-protein interaction with the PIC components and the distal SP1 monomers (reviewed in [222]). Furthermore, SP1 proteins are known to interact with TAF110 and be strictly necessary for the activation of the HIV promoter (reviewed in [222]). In another role, SP1/CTIP2 will cooperatively interact with YY1, NF- $\mathrm{KB}$ (P50-P50), SP3 and TFII-1 to recruit HDAC1, HDAC2 and HDAC3 to promote deacetylation of nucleosome 0 and 1 (nuc- 0 and nuc-1). SP1/3 can then recruit CTIP2 with Suv39H1 to promote tri-methylation of histone 3 (H3) to create a deeper latency (reviewed in [223]).

\subsubsection{RBF-2 (USF1/USF2/TFII-I)}

A cellular factor, originally termed Ras-responsive region binding factor 2 (RBF-2), binds upstream of the NF- $\mathrm{kB}$ sites and immediately downstream of the HIV TATA box to its binding sites RBEIII and RBEI, respectively (Figure 1B). RBF-2 and RBF-1 were shown to be required for the response of the HIV LTR to signals from the tyrosine kinase/Ras/Raf pathway [229]. The full identity of RBF-1 remains to be determined, but it has been shown to contain subunits GABP that bind to the RBEIV/ETS motif at positions -151 to -142 of the HIV LTR [230]. Importantly, RBEIII is a highly conserved motif [231], implying a significant role in HIV replication. Subsequent work has shown that RBF-2 is composed of at least three subunits, including USF1, USF2 and TFII-I [232,233]. Furthermore, an intact RBEIII RBF-2 binding site was shown to be critical for the activation of the HIV LTR by T cell activation [234]. Based on the above-described observations, RBF-2 (USF1/USF2/TFII-I) has emerged as a key factor in the regulation of HIV latency [228,235].

\subsection{Viral Auxiliary Proteins}

\subsubsection{Tat}

In addition to host cell transcription factors, the virally encoded proteins play a major role in HIV transcription and therefore latency. As mentioned above, the viral Tat trans-activating protein plays a central role in forming a feed-forward regulatory loop that accelerates HIV transcription via stimulation of both the initiation and the elongation of transcription [192,236]. Tat interacts directly with the nascent stem-loop RNA structure at the $5^{\prime}$ end of all viral RNAs to extract the active form of $\mathrm{p}$-TEFb for viral transcription (Figure 2). Although HIV transcription is regulated by $\mathrm{T}$ cell signals, the Tat circuitry also results in stochastic fluctuations in HIV expression, a phenomenon proposed to 
contribute to evasion of the host cell immune response [192,236]. In addition to its direct impact on HIV transcription, Tat can be secreted by infected cells without lysis [237]. Tat has also been implicated in activating the NF- $\mathrm{KB}$ pathway [238], inducing apoptosis and the inhibition of siRNA formation by Dicer (Review in [239]).

\subsection{2. $\mathrm{Vpr}$}

The Vpr (Viral protein R) protein also has multiple roles in the regulation of cellular processes to favor HIV replication. Among these roles, Vpr impacts the nuclear import of the pre-integration complex into the nucleus, blocks the cell cycle in the G2/M phase to increase viral transcription and participates in the induction of apoptosis and trans-activates the HIV-LTR and host cellular genes (Review in [239]). In the case of Vpr's impact on HIV transcription, the effect is largely indirect, acting primarily through the HIV TATA box region [150] and possibly also through the upstream elements NF- $k$ B and AP1 [240].

\section{HIV Cure/Remission Strategies}

Timothy Brown, formerly referred to as the Berlin Patient, underwent stem-cell transplantation in 2007 to treat his acute myeloid leukemia. The stem-cells were chosen from a donor that had a homozygous 32 base pair deletion in the HIV coreceptor CCR5 gene (delta32CCR5), and the outcome of the intervention is that Mr. Brown has been living without ART treatment with no viral rebound since [241]. Timothy Brown's story is an inspiration to all people living with HIV. For scientists, it provides the proof of principle that HIV can be cured. Unfortunately, the stem-cell transplantation procedure is not broadly applicable clinically due to its high mortality rate. Although Timothy Brown is the only case of an HIV cure, some individuals that received early ART treatment and were later found to naturally control HIV viremia in the absence of ART, showing that HIV remission can occur [242]. The term cure generally refers to the eradication of HIV from the patient, while the term remission, or functional cure, is most often used to describe the clinical outcome wherein the patient can live with low or undetectable virus in the absence of ART for prolonged periods without adverse impacts on disease status. In both cases, the objective is to remove the need for ongoing ART, the risk of transmission, and the stigmatization associated with HIV status. The documentation of a cure and natural cases of remission, although coming from a very small number of patients, have spurred efforts to achieve a cure or remission of HIV.

\subsection{CRISPR/Cas9}

As detailed above, transcription of the HIV provirus is the first step and a rate-limiting step in the reactivation from latency. Therefore, most cure/remission strategies will require the therapeutic manipulation of HIV transcription to attack the HIV reservoir. One exception to this rule are gene editing approaches that use the CRISPR/Cas9 system. CRISPR (Clustered Regularly Interspaced Short Palindromic Repeats) were discovered in 1987 [243], triggering the rapid development of genome editing tools now based on CRISPR Cas9. The editing exploits the Streptococcus pyogenes Cas9 protein to introduce clustered regularly interspaced short palindromic repeats with a guide RNA target. CRISPR/Cas9 can, in principle, be used to excise the HIV provirus from the genome or to host cell genes essential for HIV propagation, such as the CCR5 co-receptor (Figure 3C). Early studies raised concerns that HIV can rapidly become resistant to CRISPR/Cas9 [244], however it appears that using multiple guide RNAs to target HIV may overcome resistance [245]. Several obstacles currently lie in the way of the clinical use of CRISPR/Cas9 including the long-term safety, off-target effects, and ethical issues surrounding genome editing. Importantly, it is unclear how the CRISPR guide RNA, along with the Cas9 protein might be efficiently delivered to all reservoirs including difficult to reach tissues such as the brain or testicles. Nonetheless, CRISPR/Cas9 remains an active area of pursuit for potential future strategies to achieve an HIV cure or remission (reviewed in [246]). 

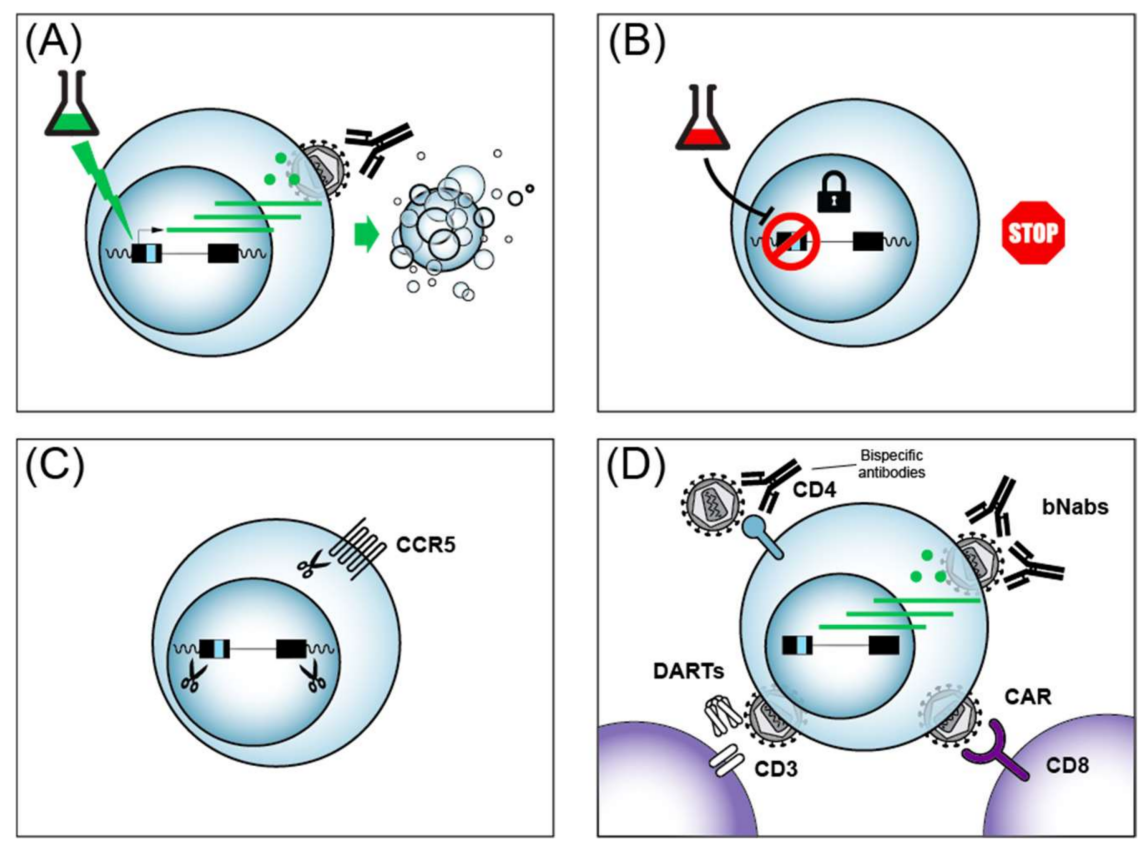

Figure 3. Four major strategies for an HIV cure or remission. (A) The shock and kill strategy to purge viral reservoirs is illustrated. See text for details. (B) The block and lock strategy for a functional cure with HIV in deep latency is illustrated. See text for details. (C) Genome editing by CRISPR/Cas9 to excise the HIV provirus or edit essential host dependency factors (e.g., CCR5). (D) Immunotherapy strategies to enhance the host cell immune response against HIV. CD4+ helper lymphocytes are in blue and CD8+ cytotoxic lymphocytes are in purple.

\subsection{Immunotherapies}

HIV infection is initially followed by a strong reduction in viremia due to the host immune response [247]. CD8+ lymphocytes have been shown to play an important role in the suppression of HIV using Simian Immunodeficiency Virus (SIV) infection in the rhesus monkey primate model [248]. The mechanisms of CD8+ cell control of HIV viremia involves direct cytotoxicity via perforin and granzyme secretion, as well as less well characterized non-cytotoxic activities (reviewed in [249]). Importantly, CD8+ cells are also required for suppression of SIV viremia and HIV [250,251], supporting the use of immunotherapy as a clinical strategy to aid in the elimination of HIV reservoirs for a cure or remission.

One gene therapy approach targeting CD8+ cells being explored towards an HIV cure includes chimeric antigen receptor (CAR)-modified immune cells that have been engineered to target HIV (reviewed in $[252,253]$ ). CAR T cells can be engineered to express T cell receptors (TCRs) that interfere with HIV replication after genetic engineering of autologous CD8+ CTL (Figure 3D). Strategies that have been investigated in HIV cure research include CARs that target HIV because the TCR contains a segment of the HIV receptor CD4, or engineering TCR that contact HIV via single-chain fragment variable (scFv) from antibody segments from broadly neutralizing antibodies (bNAbs). Early clinical trials with CAR T cells failed to reduce HIV levels because the CARs were eliminated by cytotoxic T-lymphocyte responses of patients [254], underscoring the complexity of such approaches. More recently, Hematopoietic Stem/Progenitor Cell (HSPC) gene therapy showed a more sustained CAR delivery in non-human primates [255]. Strategies to enhance anti-HIV CAR activity include the addition of signaling moieties to the engineered TCRs, such as the intracellular domains of the lymphocyte signaling molecules CD28 or CD3, and have shown encouraging anti-HIV activity with patient cells ex vivo (reviewed in [252]). The success of CAR T cell treatment of other diseases such as acute lymphoblastic leukemia (ALL) [256], provides indirect hope that such approaches might one day be applicable to people living with HIV. 
Much progress has been made in recent years identifying broadly neutralizing antibodies (bNAbs) against HIV from the B-cells of people living with HIV, and these antibodies could add to the arsenal of molecules for cure strategies (Figure 3D) (reviewed in [257]). bNAbs can be delivered to patients via infusion safely [258]. In addition to their ability to neutralize multiple strains of HIV, bNAbs have been shown to impart an unanticipated enhancement of CD8+ T cell-mediated immunity in macaque monkeys [259]. A caveat of bNAbs is that the use of a single bNAb can lead to the selection of viral escape mutations. Recently, the combined use of two bNAbs was shown to prevent viral rebound in people infected with antibody-sensitive HIV in the absence of ART [260]. bNAbs thus represent another class of cure/remission tools, likely to be used in conjunction with additional cure strategies, in the quest to eradicate HIV.

Another cure strategy that builds on the high specificity of bNAbs are bispecific antibodies that recognize HIV epitopes, but are also designed with scFvs that recognize functional proteins of the immune system with the hope of enhancing the immune response against HIV (Figure 3D) (reviewed in [261,262]). Such bispecific reagents can be used to neutralize to HIV, as shown by bispecific antibodies against HIV envelope protein (Env) and CD4 [263]. Bispecific antibodies are of particular interest in cure research, since they could potentially impact latent HIV reactivation and be immune effectors at the same time. In this vein, bispecific antibodies directed against HIV Env and the CD3 $\mathrm{T}$ cell co-receptor were shown to activate both latent HIV and target cell lysis in vitro [264]. Careful design optimization of bispecific antibodies continues to improve their potency and breadth $[265,266]$. More recently, trispecific antibodies that target against HIV were designed, underscoring the flexibility of such molecules [267]. Reagents termed Dual-Affinity Re-Targeting Molecules (DARTs) are antibody derivatives analogous to bispecific antibodies (Figure 3B), and also show promise in the recruitment of cytotoxic lymphocytes via the CD3 receptor for the killing of HIV infected CD4 cells [268,269]. Multi-specific antibodies and their derivatives have thus emerged as promising agents in the quest for an HIV cure/remission.

\subsection{HIV Transcription and Immune Evasion: A Game of Cat and Mouse?}

HIV evolved in the face of immune responses, and the hardwired latency program it encodes has presumably been selected for since it provides the advantage of evasion of the host immune system and therefore viral persistence. It is only an unfortunate consequence of HIV latency that the latent virus also evades current antiretroviral drugs, all of which only act on their targets during active viral replication. The mechanisms that permit HIV to escape host immune surveillance are limited access of antibodies to Env, antigenic variation due to high mutation rates, downregulation of the immune recognition proteins MHC I and CD4 at the cell surface by HIV Nef, the crippling of CD4 help due to the elimination of $\mathrm{CD} 4+$ cells, and the capacity of the virus to undergo latency and reactivation (reviewed in $[270,271]$ ). Of these mechanisms, perhaps the contribution of latency remains the most enigmatic. It is a game of "cat and mouse" between the immune system and HIV in which the immune system appears to have the upper hand, since viremia is initially suppressed. Virtually nothing is known about the details of this game of cat and mouse, but eventually HIV (mouse) succeeds in winning in $99 \%$ of cases, with only approximately $0.5-1 \%$ of infected individuals that control viremia in the absence of ART, termed elite controllers [272].

As the HIV promoter and the transcription factors that bind it control HIV latency, and latency itself is thought to have evolved as a means of immune evasion, the impact of promoter function on viral clearance is an important yet underexplored question. An elegant set of experiments using SIV infection of macaque monkeys and promoter exchange experiments have provided the first glimpses of the impact of promoter structure on immune clearance [273]. Infection of macaques with wild type SIV resulted in high viremia AIDS-like pathogenesis (Figure 4A). In stark contrast, the replacement of a segment of the SIV promoter that included the NF- $\mathrm{KB}$ and SP1 sites, as well as the SIV TATA box, with a roughly analogous portion of the $\mathrm{CMV}$ promoter resulted in infectious virus that produced low viremia and no disease in macaques (Figure 4B). Importantly, both the chimeric SIV/CMV promoter chimeric 
virus and the parental SIV promoter virus, produced equivalent peak levels of virus after infection of human T lymphocyte cell lines or primary PBMCs, although the SIV/CMV virus displayed delayed replication kinetics. The immunological parameters that explain the impact of promoter architecture on clearance of replicating virus remain obscure. It is noteworthy that the parental SIV virus generated stronger activation of $\mathrm{CD} 4+$ and $\mathrm{CD} 8+$ lymphocytes than the chimeric promoter containing virus as judged by increases in the number of CD69+ positive T cells. Nevertheless, the observed serum antibody responses and cellular immunity against HIV epitopes (e.g., Gag, Nef) from both the CD4+ and CD8+ compartments generated in animals infected with the parental SIV versus the SIV/CMV viruses appeared comparable. Most strikingly, not only were the animals that received the SIV strain with an exchanged promoter healthy, but they were protected against challenge with the parental SIV virus. In contrast to the promoter swapping studies of Blancou et al., one of the only other studies of the SIV promoter in rhesus monkeys showed that deletion or substitution of the NF- $\mathrm{kB}$ and SP1 motifs resulted in a virus that retained the ability to cause AIDS-like disease [274]. The results provide compelling evidence implicating the architecture of the $5^{\prime}$ LTR in determining whether SIV infection results in disease or clearance by the host immune system, and drive home the urgency of more intense investigation into the role of promoter architecture in the search for both a cure and a vaccine for HIV.

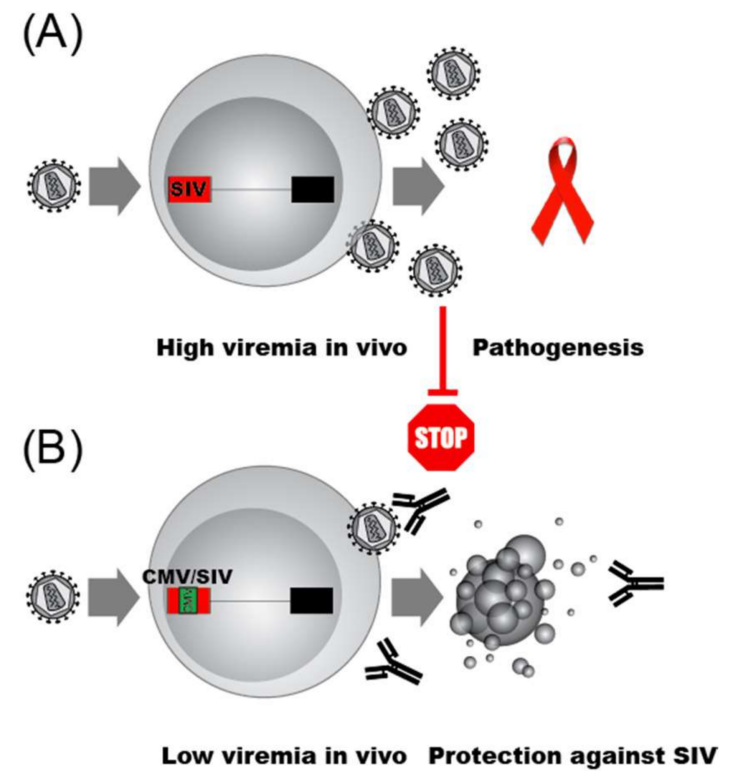

Figure 4. The essential role of the SIV LTR in immune evasion is depicted. (A) A virus containing the wild type promoter infects to produce high viremia levels and AIDS-like disease in macaque monkeys. (B) A virus with a chimeric promoter, in which a portion of the SIV promoter has been replaced by a fragment of the CMV promoter, is replication competent but produces the same peak viral output as the parental SIV in cultured cells, but low level viremia in macaque monkeys. Animals infected by a virus whose expression is driven by the SIV/CMV swapped promoter achieve immune clearance of the SIV/CMV chimeric virus and are then protected against infection by the wild type SIV virus.

Although it is not known how the promoter exchange uncoupled HIV from its immune evasion capabilities, it is likely that not only steady state transcription rates were impacted. The chimeric SIV/CMV promoter responds weakly to the viral trans-activator Tat, perhaps since the TATA box region is essential for LTRs activation by Tat (reviewed in [173]). Similarly, HIV Vpr acts through the elements of the SIV promoter that were exchanged in the SIV/CMV [150]. How the viral promoter allows HIV immune escape remains completely unknown. One purely speculative conceptual framework we evoke is that the very rapid response of the virus to extracellular cues from host immune cells permits at least some virus-infected cells to avoid killing, analogous to the way a boxer avoids being punched by "slipping" the opponents oncoming blow, before counterpunching. Evidence that the speed of viral 
replication versus the speed of the $\mathrm{T}$ cell infiltration can impact viral escape has been reported for SIV [275]. We note as a possible player in immune escape that CD8+ cells are thought to inhibit HIV transcription (reviewed in [249]), although the possible mechanisms responsible remain to be fully defined [276,277]. One thing is clear: Further investigation into how the specific architecture of the HIV promoter allows the virus to evade immune clearance is important to achieve not only an HIV cure, but also an effective vaccine.

\subsection{Shock and Kill}

One strategy to eliminate latent reservoirs of HIV from infected people that has to date garnered the lion's share of effort and resources has been called the shock and kill (or kick and kill) approach that has been extensively reviewed [278-281]. The approach is conceptually straight forward, and involves the activation of latent HIV so that the virus can then be eliminated by ART treatment, almost certainly in conjunction with immunotherapy (Figure 3A). Much progress has been made in the identification of latency reversing agents (LRAs) that act on host cell transcription factors to induce HIV gene expression. The most common LRAs act through three main mechanisms: (i) NF- $\mathrm{kB}$ activation; (ii) HDAC inhibition; or (iii) mimic HIV Tat by driving the formation of the active form of P-TEFb from its inactive 7SK snRNP-bound form. For brevity, we present a summary of several common LRAs and their targets in Table 1. Although LRAs, or combinations thereof, indeed activate HIV expression in vitro and in vivo, clinical trials to date have failed to show any decrease in the viral reservoirs (reviewed in [280]) by shock and kill, even when used in combination with HIV vaccines [282]. There are many avenues that remain to be explored in the optimization of the shock and kill approach, yet there are daunting obstacles to overcome as well. In particular, recent work shows that LRAs activate HIV expression from not more than $5 \%$ of latently infected primary CD4+ cells, even when used in combination [73]. Another hurdle to overcome to achieve efficient shock and kill, is the recently reported observation that the treatment of HIV infected people with LRAs such as the HDAC inhibitor romidepsin only increased early HIV transcription initiation and elongation, without significant impacts on later events such as transcriptional completion and multiple splicing [283]. These findings imply that later steps in HIV gene expression in addition to transcription will have to be targeted for effectively purging HIV reservoirs. Although the shock and kill cure approach remains a highly active area of research, the preponderance of evidence provided to date underscores the strategic importance of also pursuing alternative ways to achieve an HIV cure/remission.

Table 1. A list of characterized HIV latency reversal agents (LRAs).

\begin{tabular}{ccc}
\hline Latency Reversing Agent (LRA) $^{*}$ & LRA Class (Target/Pathway) & Reference (s) \\
\hline Valproic acid & HDAC inhibitor & {$[284]$} \\
SAHA & HDAC inhibitor & {$[285]$} \\
Romidepsin & HDAC inhibitor & {$[286]$} \\
JQ1 & BET domain inhibitor/BRD4 & {$[199]$} \\
MMQO & BET domain inhibitor/BRD4 & {$[201]$} \\
Prostratin & Stimulates PKC/NF- $\kappa$ B & {$[287]$} \\
BIX01294 & Methyltransferase inhibitor & {$[288]$} \\
\hline
\end{tabular}

* Note that to date clinical trials with LRAs have not shown a significant reduction in viral reservoirs (see text).

\subsection{Block and Lock}

A strategy distinct from the shock and kill HIV cure approach that is drawing increasing attention is a remission strategy termed block and lock (Figure 3B). The term block and lock has been coined relatively recently to describe a strategy to induce a deep and permanent state of HIV latency to achieve a functional cure (remission) for HIV [289]. The idea of inhibiting HIV transcription to develop anti-HIV drugs predates the ART era (reviewed in [290]), but it is only recently that long sought inhibitors of HIV Tat have been discovered. The small molecule didehydro-Cortistatin A (dCA) binds to HIV Tat to 
inhibit Tat-mediated trans-activation [291]. Recently, it has been shown that dCA binds selectively to the unstructured basic region of Tat to prevent the Tat-TAR RNA interaction [292]. dCA prevents viral reactivation from patient CD4+ cells ex vivo [293]. Even more encouragingly, dCA treatment slows viral rebound after ART withdrawal in a humanized mouse model [289]. dCA has therefore emerged as an appealing latency promoting agent (LPA) for block and lock remission. The dCA target Tat has been shown to counteract the cleavage of TAR into small RNAs that are proposed to feed back to negatively regulate the HIV LTR via epigenetic changes [294]. Therefore, recent advances in the understanding of the role of cellular proteins involved in TAR processing may provide a rich source of potential drug targets for novel block and lock treatments that impact the epigenetic state of the LTR [295]. In addition to dCA, another LPA showing promise is ABX464, a small molecule that interacts with Cap Binding Complex (CBC) to prevent HIV Rev-mediated nuclear export of unspliced HIV transcripts [296]. ABX464 was shown to block viral rebound after ART removal in humanized mice, and more recently was also reported to be well tolerated in humans [297]. ABX464 is currently in clinical trials for the treatment of ulcerative colitis, and a recent next generation transcriptome sequencing suggests it may act by enhancing the splicing of HIV [298]. Building on these findings, we anticipate an acceleration of efforts to improve existing LPAs, identify novel LPAs from natural sources, chemical screening and rational design (reviewed in [299]), as well as the testing of LPA in animal models and clinical trials. Recently, curaxin 100 [300] and levosimendan [301] were reported as new potential LPAs that inhibit HIV transcription. Table 2 summarizes potential small molecule LPAs and their impacts on HIV.

The block and lock strategy has several potential advantages over the shock and kill strategy. Firstly, while clinical trials to date suggest that ART interruption does not represent a major health risk, the possibility of adverse effects with viral reactivation are difficult to rule out. In contrast to shock and kill, the block and lock strategy inhibits HIV reactivation, therefore avoiding safety concerns related to increased HIV replication. Secondly, the development of block and lock reagents, should they fail to achieve a functional cure, would still be of clinical value since these drugs would represent new antiretrovirals that could be used in the case of drug resistance. A third advantage, which remains hypothetical, is that, unlike LRAs, LPAs may uncouple HIV gene expression from immune system cues (e.g., CD8+ CTLs), enhancing immune clearance. The prediction of this hypothesis can be tested in primate models, in which the efficiency of immune clearance of SIV is monitored in response to LPA treatments.

In addition to small molecule approaches to block and lock, gene therapy approaches are being explored. For example, shRNAs that target the HIV LTR were recently shown to induce epigenetic silencing and block reactivation of HIV in cultured cell models of HIV latency [302]. In another approach, HEXIM1-Tat chimeric peptides were reported to block HIV reactivation in cell lines [303]. While there is currently no efficient way to deliver shRNAs or peptides to HIV reservoirs in patients, these findings could pave the way to improved LPAs in the future. In summary, recent progress in development of block and lock strategies have generated a growing optimism that such a strategy could be used in the future to bring about a functional cure for HIV.

Table 2. A list of potential HIV latency promoting agents (LPAs).

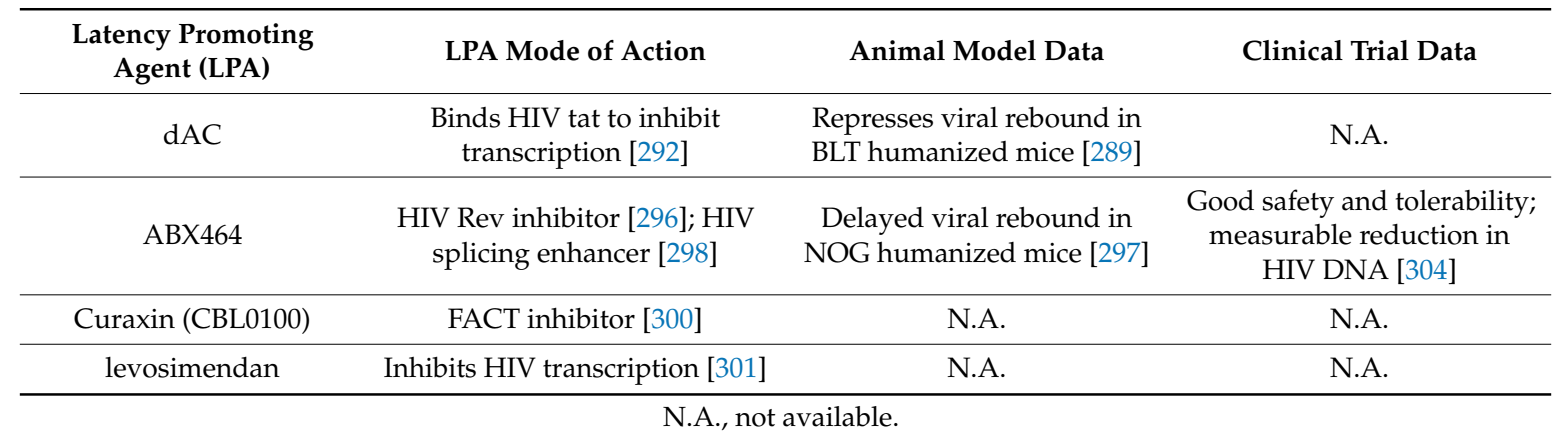




\subsection{Other Cure/Remission Strategies}

In addition to the strategies described above, fresh approaches are continually being conceived and tested in the quest for a cure/remission. One of these strategies includes the use of HIV-dependent suicide gene therapy vectors to kill cells of the latent reservoir [305]. A second alternative strategy is the selective killing of latently infected cells with oncolytic viruses, a method that has shown encouraging results in cultured cells [306]. A third alternative approach is the use of Smac mimetics to reverse HIV latency [307] and selectively induce death of latently infected cells [280]. A fourth notable approach to deplete the latent reservoirs entails the use of small molecule inhibitors of HIV Nef function to enhance the CD8 T cell-mediated elimination of latently infected cells [308]. Finally, we note more than one of the cure/remission strategies could be combined to synergistically achieve a functional cure in the clinic.

\section{Conclusions and Perspectives}

It is not yet clear which cure/remission strategies will be the most effective in achieving an HIV / AIDS free world. Along the inexorable but difficult pathway to a cure/remission, it is worth being reminded of the lessons learned from earlier hard-fought victories against HIV / AIDS. Firstly, members of the HIV infected population must be included at all stages of the fight, from advocacy to the conception and analysis of biomedical studies and clinical trials [309]. Secondly, despite our zeal to rapidly move cure/remission strategies into the clinic, we must not lose sight of the critical gaps in our biological knowledge of HIV. Lifesaving ART was only made possible once basic science gave us an intimate knowledge of the drug targets and their role in the HIV life cycle. Thirdly, and most importantly, HIV / AIDS is a global problem and any cure/strategy that will succeed must be able to be implemented in resource-limited areas of the world.

Here, we have highlighted the growing interest in the block and lock strategy to achieve an HIV remission. We suggest that small molecules would be an affordable and scalable way to achieve block and lock, and that such drugs may also potentially cripple the virus' ability to escape host immune surveillance. Finally, we point to the gap in our knowledge of the cat and mouse-like interaction between the immune system and HIV that underpins HIV persistence as a crucial area for investigation in the coming years.

The goal of achieving an HIV cure or remission is important for the 36.9 million people currently living with HIV, but also as a means to definitively halt the HIV pandemic for future generations. Furthermore, should a cure and/or remission for HIV be discovered, it would at last open the way to curing other pathogenic infections that depend on latency for their persistence, such as herpes viruses (e.g., HSV1, HSV2, and EBV) (reviewed in [310]), chronic viral pathogens that have yet to emerge, and perhaps even latent bacteria, such a Mycobacterium tuberculosis (reviewed in [311]).

Supplementary Materials: The following are available online at http:/ / www.mdpi.com/1999-4915/11/3/269/s1, Table S1: A list of miRNAs putatively involved in the regulation of HIV-1 latency.

Funding: Work on HIV cure research was supported by a CIHR Operating Grant (Funding Reference Number CHR-126637), and by The Canadian HIV Cure Enterprise Team Grant HIG-133050 to B.B. from the CIHR in partnership with CANFAR and IAS.

Acknowledgments: We thank Annie Leclerc for assistance in the preparation of figures. We thank all members of CanCURE for helpful discussions. We thank two anonymous reviewers, John Rohde, Arndt Benecke and Robert Reinhard for critical comments on the manuscript.

Conflicts of Interest: The authors declare no conflict of interest. The funders had no role in the design of the study; in the collection, analyses, or interpretation of data; in the writing of the manuscript, or in the decision to publish the results.

\section{References}

1. Barré-Sinoussi, F.; Chermann, J.C.; Rey, F.; Nugeyre, M.T.; Chamaret, S.; Gruest, J.; Dauguet, C.; Axler-Blin, C.; Vézinet-Brun, F.; Rouzioux, C.; et al. Isolation of a T-lymphotropic retrovirus from a patient at risk for acquired immune deficiency syndrome (AIDS). Science 1983, 220, 868-871. [CrossRef] 
2. Global HIV \& AIDS Statistics-2018 Fact Sheet. UNAIDS. Available online: http:/ /www.unaids.org/en/ resources / fact-sheet (accessed on 14 January 2019).

3. Joint United Nations Programme on HIV / AIDS (UNAIDS). Progress towards the 90-90-90 Targets Ending AIDS GLOBAL AIDS UPDATE. 2017. Available online: http:/ /www.unaids.org/en/resources/campaigns / globalAIDSupdate2017 (accessed on 3 March 2019).

4. Seatla, K.K.; Avalos, A.; Moyo, S.; Mine, M.; Diphoko, T.; Mosepele, M.; Gaolatlhe, T.; Rowley, C.F.; Ramaabya, D.; Jarvis, J.N.; et al. Four-class drug-resistant HIV-1 subtype C in a treatment experienced individual on dolutegravir-based antiretroviral therapy in Botswana. AIDS 2018, 32, 1899-1902. [CrossRef]

5. Jordan, M.R.; Dean, N.E.; World Health Organization. Department of HIV/AIDS; Bill \& Melinda Gates Foundation; United States President's Emergency Plan for AIDS Relief. Global Report on Early Warning Indicators of HIV Drug Resistance: Technical Report; WHO: Geneva, Switzerland, 2016; ISBN 9789241511179.

6. Chomont, N.; El-Far, M.; Ancuta, P.; Trautmann, L.; Procopio, F.A.; Yassine-Diab, B.; Boucher, G.; Boulassel, M.-R.; Ghattas, G.; Brenchley, J.M.; et al. HIV reservoir size and persistence are driven by T cell survival and homeostatic proliferation. Nat. Med. 2009, 15, 893-900. [CrossRef]

7. Siliciano, R.F.; Greene, W.C. HIV latency. Cold Spring Harb. Perspect. Med. 2011, 1, a007096. [CrossRef]

8. Chun, T.-W.; Justement, J.S.; Murray, D.; Hallahan, C.W.; Maenza, J.; Collier, A.C.; Sheth, P.M.; Kaul, R.; Ostrowski, M.; Moir, S.; et al. Rebound of plasma viremia following cessation of antiretroviral therapy despite profoundly low levels of HIV reservoir: Implications for eradication. AIDS 2010, 24, 2803-2808. [CrossRef] [PubMed]

9. Jain, V.; Hartogensis, W.; Bacchetti, P.; Hunt, P.W.; Hatano, H.; Sinclair, E.; Epling, L.; Lee, T.-H.; Busch, M.P.; McCune, J.M.; et al. Antiretroviral therapy initiated within 6 months of HIV infection is associated with lower T-cell activation and smaller HIV reservoir size. J. Infect. Dis. 2013, 208, 1202-1211. [CrossRef] [PubMed]

10. Chun, T.W.; Engel, D.; Berrey, M.M.; Shea, T.; Corey, L.; Fauci, A.S. Early establishment of a pool of latently infected, resting CD4(+) T cells during primary HIV-1 infection. Proc. Natl. Acad. Sci. USA 1998, 95, 8869-8873. [CrossRef]

11. Lee, G.Q.; Lichterfeld, M. Diversity of HIV-1 reservoirs in CD4 ${ }^{+}$T-cell subpopulations. Curr. Opin. HIV AIDS 2016, 11, 383-387. [CrossRef]

12. Barton, K.; Winckelmann, A.; Palmer, S. HIV-1 Reservoirs During Suppressive Therapy. Trends Microbiol. 2016, 24, 345-355. [CrossRef] [PubMed]

13. von Stockenstrom, S.; Odevall, L.; Lee, E.; Sinclair, E.; Bacchetti, P.; Killian, M.; Epling, L.; Shao, W.; Hoh, R.; Ho, T.; et al. Longitudinal Genetic Characterization Reveals That Cell Proliferation Maintains a Persistent HIV Type 1 DNA Pool During Effective HIV Therapy. J. Infect. Dis. 2015, 212, 596-607. [CrossRef]

14. Wightman, F.; Solomon, A.; Khoury, G.; Green, J.A.; Gray, L.; Gorry, P.R.; Ho, Y.S.; Saksena, N.K.; Hoy, J.; Crowe, S.M.; et al. Both CD31(+) and CD31- naive CD4(+) T cells are persistent HIV type 1-infected reservoirs in individuals receiving antiretroviral therapy. J. Infect. Dis. 2010, 202, 1738-1748. [CrossRef] [PubMed]

15. Soriano-Sarabia, N.; Bateson, R.E.; Dahl, N.P.; Crooks, A.M.; Kuruc, J.D.; Margolis, D.M.; Archin, N.M. Quantitation of replication-competent HIV-1 in populations of resting CD4 ${ }^{+}$T cells. J. Virol. 2014, 88, 14070-14077. [CrossRef]

16. Kovacs, J.A.; Lempicki, R.A.; Sidorov, I.A.; Adelsberger, J.W.; Sereti, I.; Sachau, W.; Kelly, G.; Metcalf, J.A.; Davey, R.T.; Falloon, J.; et al. Induction of prolonged survival of CD4 ${ }^{+} \mathrm{T}$ lymphocytes by intermittent IL-2 therapy in HIV-infected patients. J. Clin. Investig. 2005, 115, 2139-2148. [CrossRef] [PubMed]

17. Vandergeeten, C.; Fromentin, R.; DaFonseca, S.; Lawani, M.B.; Sereti, I.; Lederman, M.M.; Ramgopal, M.; Routy, J.-P.; Sékaly, R.-P.; Chomont, N. Interleukin-7 promotes HIV persistence during antiretroviral therapy. Blood 2013, 121, 4321-4329. [CrossRef]

18. Jaafoura, S.; de Goër de Herve, M.G.; Hernandez-Vargas, E.A.; Hendel-Chavez, H.; Abdoh, M.; Mateo, M.C.; Krzysiek, R.; Merad, M.; Seng, R.; Tardieu, M.; et al. Progressive contraction of the latent HIV reservoir around a core of less-differentiated CD4 ${ }^{+}$memory T Cells. Nat. Commun. 2014, 5, 5407. [CrossRef]

19. Darshan, R.; Leblois, A.; Hansel, D. Interference and shaping in sensorimotor adaptations with rewards. PLoS Comput. Biol. 2014, 10, e1003377. [CrossRef] 
20. Gosselin, A.; Monteiro, P.; Chomont, N.; Diaz-Griffero, F.; Said, E.A.; Fonseca, S.; Wacleche, V.; El-Far, M.; Boulassel, M.-R.; Routy, J.-P.; et al. Peripheral blood CCR4 ${ }^{+} \mathrm{CCR}^{+}$and $\mathrm{CXCR}^{+} \mathrm{CCR}^{+} \mathrm{CD} 4^{+} \mathrm{T}$ cells are highly permissive to HIV-1 infection. J. Immunol. 2010, 184, 1604-1616. [CrossRef] [PubMed]

21. Muranski, P.; Restifo, N.P. Essentials of Th17 cell commitment and plasticity. Blood 2013, 121, $2402-2414$. [CrossRef]

22. Wei, S.; Zhao, E.; Kryczek, I.; Zou, W. Th17 cells have stem cell-like features and promote long-term immunity. Oncoimmunology 2012, 1, 516-519. [CrossRef] [PubMed]

23. Sun, H.; Kim, D.; Li, X.; Kiselinova, M.; Ouyang, Z.; Vandekerckhove, L.; Shang, H.; Rosenberg, E.S.; Yu, X.G.; Lichterfeld, M. Th1/17 Polarization of CD4 T Cells Supports HIV-1 Persistence during Antiretroviral Therapy. J. Virol. 2015, 89, 11284-11293. [CrossRef] [PubMed]

24. Wacleche, V.S.; Goulet, J.-P.; Gosselin, A.; Monteiro, P.; Soudeyns, H.; Fromentin, R.; Jenabian, M.-A.; Vartanian, S.; Deeks, S.G.; Chomont, N.; et al. New insights into the heterogeneity of Th17 subsets contributing to HIV-1 persistence during antiretroviral therapy. Retrovirology 2016, 13, 59. [CrossRef]

25. Perreau, M.; Savoye, A.-L.; de Crignis, E.; Corpataux, J.-M.; Cubas, R.; Haddad, E.K.; de Leval, L.; Graziosi, C.; Pantaleo, G. Follicular helper T cells serve as the major CD4 T cell compartment for HIV-1 infection, replication, and production. J. Exp. Med. 2013, 210, 143-156. [CrossRef] [PubMed]

26. Morita, R.; Schmitt, N.; Bentebibel, S.-E.; Ranganathan, R.; Bourdery, L.; Zurawski, G.; Foucat, E.; Dullaers, M.; Oh, S.; Sabzghabaei, N.; et al. Human blood CXCR5(+)CD4(+) T cells are counterparts of T follicular cells and contain specific subsets that differentially support antibody secretion. Immunity 2011, 34, 108-121. [CrossRef]

27. Schultz, B.T.; Teigler, J.E.; Pissani, F.; Oster, A.F.; Kranias, G.; Alter, G.; Marovich, M.; Eller, M.A.; Dittmer, U.; Robb, M.L.; et al. Circulating HIV-Specific Interleukin-21(+)CD4(+) T Cells Represent Peripheral Tfh Cells with Antigen-Dependent Helper Functions. Immunity 2016, 44, 167-178. [CrossRef]

28. Pallikkuth, S.; Sharkey, M.; Babic, D.Z.; Gupta, S.; Stone, G.W.; Fischl, M.A.; Stevenson, M.; Pahwa, S. Peripheral T Follicular Helper Cells Are the Major HIV Reservoir within Central Memory CD4 T Cells in Peripheral Blood from Chronically HIV-Infected Individuals on Combination Antiretroviral Therapy. J. Virol. 2015, 90, 2718-2728. [CrossRef]

29. García, M.; Górgolas, M.; Cabello, A.; Estrada, V.; Ligos, J.M.; Fernández-Guerrero, M.; Barros, C.; López-Bernaldo, J.C.; De La Hera, F.J.; Montoya, M.; et al. Peripheral T follicular helper Cells Make a Difference in HIV Reservoir Size between Elite Controllers and Patients on Successful cART. Sci. Rep. 2017, 7, 16799. [CrossRef]

30. Soriano-Sarabia, N.; Archin, N.M.; Bateson, R.; Dahl, N.P.; Crooks, A.M.; Kuruc, J.D.; Garrido, C.; Margolis, D.M. Peripheral V $\gamma 9$ V82 T Cells Are a Novel Reservoir of Latent HIV Infection. PLoS Pathog. 2015, 11, e1005201. [CrossRef]

31. Maddon, P.J.; Dalgleish, A.G.; McDougal, J.S.; Clapham, P.R.; Weiss, R.A.; Axel, R. The T4 gene encodes the AIDS virus receptor and is expressed in the immune system and the brain. Cell 1986, 47, 333-348. [CrossRef]

32. Lifson, J.D.; Feinberg, M.B.; Reyes, G.R.; Rabin, L.; Banapour, B.; Chakrabarti, S.; Moss, B.; Wong-Staal, F.; Steimer, K.S.; Engleman, E.G. Induction of CD4-dependent cell fusion by the HTLV-III/LAV envelope glycoprotein. Nature 1986, 323, 725-728. [CrossRef]

33. Koenig, S.; Gendelman, H.E.; Orenstein, J.M.; Dal Canto, M.C.; Pezeshkpour, G.H.; Yungbluth, M.; Janotta, F.; Aksamit, A.; Martin, M.A.; Fauci, A.S. Detection of AIDS virus in macrophages in brain tissue from AIDS patients with encephalopathy. Science 1986, 233, 1089-1093. [CrossRef]

34. Gendelman, H.E.; Orenstein, J.M.; Martin, M.A.; Ferrua, C.; Mitra, R.; Phipps, T.; Wahl, L.A.; Lane, H.C.; Fauci, A.S.; Burke, D.S. Efficient isolation and propagation of human immunodeficiency virus on recombinant colony-stimulating factor 1-treated monocytes. J. Exp. Med. 1988, 167, 1428-1441. [CrossRef] [PubMed]

35. Zhu, T.; Muthui, D.; Holte, S.; Nickle, D.; Feng, F.; Brodie, S.; Hwangbo, Y.; Mullins, J.I.; Corey, L. Evidence for human immunodeficiency virus type 1 replication in vivo in CD14(+) monocytes and its potential role as a source of virus in patients on highly active antiretroviral therapy. J. Virol. 2002, 76, 707-716. [CrossRef] [PubMed]

36. Swingler, S.; Brichacek, B.; Jacque, J.-M.; Ulich, C.; Zhou, J.; Stevenson, M. HIV-1 Nef intersects the macrophage CD40L signalling pathway to promote resting-cell infection. Nature 2003, 424, 213-219. [CrossRef] [PubMed]

37. Kelly, J.; Beddall, M.H.; Yu, D.; Iyer, S.R.; Marsh, J.W.; Wu, Y. Human macrophages support persistent transcription from unintegrated HIV-1 DNA. Virology 2008, 372, 300-312. [CrossRef] 
38. Churchill, M.J.; Gorry, P.R.; Cowley, D.; Lal, L.; Sonza, S.; Purcell, D.F.J.; Thompson, K.A.; Gabuzda, D.; McArthur, J.C.; Pardo, C.A.; et al. Use of laser capture microdissection to detect integrated HIV-1 DNA in macrophages and astrocytes from autopsy brain tissues. J. Neurovirol. 2006, 12, 146-152. [CrossRef] [PubMed]

39. Schmitz, J.; van Lunzen, J.; Tenner-Racz, K.; Grossschupff, G.; Racz, P.; Schmitz, H.; Dietrich, M.; Hufert, F.T. Follicular dendritic cells retain HIV-1 particles on their plasma membrane, but are not productively infected in asymptomatic patients with follicular hyperplasia. J. Immunol. 1994, 153, 1352-1359.

40. Heath, S.L.; Tew, J.G.; Tew, J.G.; Szakal, A.K.; Burton, G.F. Follicular dendritic cells and human immunodeficiency virus infectivity. Nature 1995, 377, 740-744. [CrossRef] [PubMed]

41. Sathaliyawala, T.; Kubota, M.; Yudanin, N.; Turner, D.; Camp, P.; Thome, J.J.C.; Bickham, K.L.; Lerner, H.; Goldstein, M.; Sykes, M.; et al. Distribution and compartmentalization of human circulating and tissue-resident memory T cell subsets. Immunity 2013, 38, 187-197. [CrossRef]

42. Noto, A.; Procopio, F.A.; Banga, R.; Suffiotti, M.; Corpataux, J.-M.; Cavassini, M.; Riva, A.; Fenwick, C.; Gottardo, R.; Perreau, M.; et al. CD32 ${ }^{+}$and PD-1+ Lymph Node CD4 T Cells Support Persistent HIV-1 Transcription in Treated Aviremic Individuals. J. Virol. 2018, 92, e00901-18. [CrossRef]

43. Chun, T.-W.; Nickle, D.C.; Justement, J.S.; Meyers, J.H.; Roby, G.; Hallahan, C.W.; Kottilil, S.; Moir, S.; Mican, J.M.; Mullins, J.I.; et al. Persistence of HIV in gut-associated lymphoid tissue despite long-term antiretroviral therapy. J. Infect. Dis. 2008, 197, 714-720. [CrossRef]

44. Clark, R.A.; Watanabe, R.; Teague, J.E.; Schlapbach, C.; Tawa, M.C.; Adams, N.; Dorosario, A.A.; Chaney, K.S.; Cutler, C.S.; Leboeuf, N.R.; et al. Skin effector memory T cells do not recirculate and provide immune protection in alemtuzumab-treated CTCL patients. Sci. Transl. Med. 2012, 4, 117ra7. [CrossRef] [PubMed]

45. Watanabe, R.; Gehad, A.; Yang, C.; Scott, L.L.; Teague, J.E.; Schlapbach, C.; Elco, C.P.; Huang, V.; Matos, T.R.; Kupper, T.S.; et al. Human skin is protected by four functionally and phenotypically discrete populations of resident and recirculating memory T cells. Sci. Transl. Med. 2015, 7, 279ra39. [CrossRef] [PubMed]

46. Schnell, G.; Spudich, S.; Harrington, P.; Price, R.W.; Swanstrom, R. Compartmentalized human immunodeficiency virus type 1 originates from long-lived cells in some subjects with HIV-1-associated dementia. PLoS Pathog. 2009, 5, e1000395. [CrossRef] [PubMed]

47. Banga, R.; Procopio, F.A.; Noto, A.; Pollakis, G.; Cavassini, M.; Ohmiti, K.; Corpataux, J.-M.; de Leval, L.; Pantaleo, G.; Perreau, M. PD-1(+) and follicular helper T cells are responsible for persistent HIV-1 transcription in treated aviremic individuals. Nat. Med. 2016, 22, 754-761. [CrossRef]

48. Boritz, E.A.; Darko, S.; Swaszek, L.; Wolf, G.; Wells, D.; Wu, X.; Henry, A.R.; Laboune, F.; Hu, J.; Ambrozak, D.; et al. Multiple Origins of Virus Persistence during Natural Control of HIV Infection. Cell 2016, 166, 1004-1015. [CrossRef] [PubMed]

49. Schacker, T.; Little, S.; Connick, E.; Gebhard, K.; Zhang, Z.Q.; Krieger, J.; Pryor, J.; Havlir, D.; Wong, J.K.; Schooley, R.T.; et al. Productive infection of T cells in lymphoid tissues during primary and early human immunodeficiency virus infection. J. Infect. Dis. 2001, 183, 555-562. [CrossRef] [PubMed]

50. Di Mascio, M.; Srinivasula, S.; Bhattacharjee, A.; Cheng, L.; Martiniova, L.; Herscovitch, P.; Lertora, J.; Kiesewetter, D. Antiretroviral tissue kinetics: In vivo imaging using positron emission tomography. Antimicrob. Agents Chemother. 2009, 53, 4086-4095. [CrossRef] [PubMed]

51. Roulet, V.; Satie, A.-P.; Ruffault, A.; Le Tortorec, A.; Denis, H.; Guist'hau, O.; Patard, J.-J.; Rioux-Leclerq, N.; Gicquel, J.; Jégou, B.; et al. Susceptibility of human testis to human immunodeficiency virus-1 infection in situ and in vitro. Am. J. Pathol. 2006, 169, 2094-2103. [CrossRef]

52. Huang, Y.; Hoque, M.T.; Jenabian, M.-A.; Vyboh, K.; Whyte, S.-K.; Sheehan, N.L.; Brassard, P.; Bélanger, M.; Chomont, N.; Fletcher, C.V.; et al. Antiretroviral drug transporters and metabolic enzymes in human testicular tissue: Potential contribution to HIV-1 sanctuary site. J. Antimicrob. Chemother. 2016, 71, 1954-1965. [CrossRef]

53. Macallan, D.C.; Borghans, J.A.M.; Asquith, B. Human T Cell Memory: A Dynamic View. Vaccines 2017, 5, 5. [CrossRef]

54. Hammarlund, E.; Lewis, M.W.; Hansen, S.G.; Strelow, L.I.; Nelson, J.A.; Sexton, G.J.; Hanifin, J.M.; Slifka, M.K. Duration of antiviral immunity after smallpox vaccination. Nat. Med. 2003, 9, 1131-1137. [CrossRef] [PubMed]

55. Agosto, L.M.; Herring, M.B.; Mothes, W.; Henderson, A.J. HIV-1-Infected CD4 ${ }^{+}$T Cells Facilitate Latent Infection of Resting CD4 ${ }^{+}$T Cells through Cell-Cell Contact. Cell Rep. 2018, 24, 2088-2100. [CrossRef] 
56. Josefsson, L.; von Stockenstrom, S.; Faria, N.R.; Sinclair, E.; Bacchetti, P.; Killian, M.; Epling, L.; Tan, A.; Ho, T.; Lemey, P.; et al. The HIV-1 reservoir in eight patients on long-term suppressive antiretroviral therapy is stable with few genetic changes over time. Proc. Natl. Acad. Sci. USA 2013, 110, E4987-E4996. [CrossRef]

57. Kieffer, T.L.; Finucane, M.M.; Nettles, R.E.; Quinn, T.C.; Broman, K.W.; Ray, S.C.; Persaud, D.; Siliciano, R.F. Genotypic analysis of HIV-1 drug resistance at the limit of detection: Virus production without evolution in treated adults with undetectable HIV loads. J. Infect. Dis. 2004, 189, 1452-1465. [CrossRef]

58. Mens, H.; Pedersen, A.G.; Jørgensen, L.B.; Hue, S.; Yang, Y.; Gerstoft, J.; Katzenstein, T.L. Investigating signs of recent evolution in the pool of proviral HIV type 1 DNA during years of successful HAART. AIDS Res. Hum. Retrovir. 2007, 23, 107-115. [CrossRef] [PubMed]

59. Bosque, A.; Famiglietti, M.; Weyrich, A.S.; Goulston, C.; Planelles, V. Homeostatic proliferation fails to efficiently reactivate HIV-1 latently infected central memory CD4 ${ }^{+}$T cells. PLoS Pathog. 2011, 7, e1002288. [CrossRef] [PubMed]

60. Laird, G.M.; Eisele, E.E.; Rabi, S.A.; Lai, J.; Chioma, S.; Blankson, J.N.; Siliciano, J.D.; Siliciano, R.F. Rapid quantification of the latent reservoir for HIV-1 using a viral outgrowth assay. PLoS Pathog. 2013, 9, e1003398. [CrossRef] [PubMed]

61. Ho, Y.-C.; Shan, L.; Hosmane, N.N.; Wang, J.; Laskey, S.B.; Rosenbloom, D.I.S.; Lai, J.; Blankson, J.N.; Siliciano, J.D.; Siliciano, R.F. Replication-competent noninduced proviruses in the latent reservoir increase barrier to HIV-1 cure. Cell 2013, 155, 540-551. [CrossRef] [PubMed]

62. Hosmane, N.N.; Kwon, K.J.; Bruner, K.M.; Capoferri, A.A.; Beg, S.; Rosenbloom, D.I.S.; Keele, B.F.; Ho, Y.-C.; Siliciano, J.D.; Siliciano, R.F. Proliferation of latently infected $\mathrm{CD}^{+} \mathrm{T}$ cells carrying replication-competent HIV-1: Potential role in latent reservoir dynamics. J. Exp. Med. 2017, 214, 959-972. [CrossRef] [PubMed]

63. Buzon, M.J.; Sun, H.; Li, C.; Shaw, A.; Seiss, K.; Ouyang, Z.; Martin-Gayo, E.; Leng, J.; Henrich, T.J.; Li, J.Z.; et al. HIV-1 persistence in CD4 ${ }^{+}$T cells with stem cell-like properties. Nat. Med. 2014, 20, 139-142. [CrossRef]

64. Carr, J.M.; Hocking, H.; Li, P.; Burrell, C.J. Rapid and efficient cell-to-cell transmission of human immunodeficiency virus infection from monocyte-derived macrophages to peripheral blood lymphocytes. Virology 1999, 265, 319-329. [CrossRef] [PubMed]

65. Chen, P.; Hübner, W.; Spinelli, M.A.; Chen, B.K. Predominant mode of human immunodeficiency virus transfer between $\mathrm{T}$ cells is mediated by sustained Env-dependent neutralization-resistant virological synapses. J. Virol. 2007, 81, 12582-12595. [CrossRef] [PubMed]

66. Massanella, M.; Richman, D.D. Measuring the latent reservoir in vivo. J. Clin. Investig. 2016, 126, 464-472. [CrossRef] [PubMed]

67. Fun, A.; Mok, H.P.; Wills, M.R.; Lever, A.M. A highly reproducible quantitative viral outgrowth assay for the measurement of the replication-competent latent HIV-1 reservoir. Sci. Rep. 2017, 7, 43231. [CrossRef] [PubMed]

68. Bruner, K.M.; Murray, A.J.; Pollack, R.A.; Soliman, M.G.; Laskey, S.B.; Capoferri, A.A.; Lai, J.; Strain, M.C.; Lada, S.M.; Hoh, R.; et al. Defective proviruses rapidly accumulate during acute HIV-1 infection. Nat. Med. 2016, 22, 1043-1049. [CrossRef]

69. Eriksson, S.; Graf, E.H.; Dahl, V.; Strain, M.C.; Yukl, S.A.; Lysenko, E.S.; Bosch, R.J.; Lai, J.; Chioma, S.; Emad, F.; et al. Comparative analysis of measures of viral reservoirs in HIV-1 eradication studies. PLoS Pathog. 2013, 9, e1003174. [CrossRef] [PubMed]

70. Baxter, A.E.; Niessl, J.; Fromentin, R.; Richard, J.; Porichis, F.; Massanella, M.; Brassard, N.; Alsahafi, N.; Routy, J.-P.; Finzi, A.; et al. Multiparametric characterization of rare HIV-infected cells using an RNA-flow FISH technique. Nat. Protoc. 2017, 12, 2029-2049. [CrossRef]

71. Calvanese, V.; Chavez, L.; Laurent, T.; Ding, S.; Verdin, E. Dual-color HIV reporters trace a population of latently infected cells and enable their purification. Virology 2013, 446, 283-292. [CrossRef] [PubMed]

72. Kok, Y.L.; Schmutz, S.; Inderbitzin, A.; Neumann, K.; Kelley, A.; Jörimann, L.; Shilaih, M.; Vongrad, V.; Kouyos, R.D.; Günthard, H.F.; et al. Spontaneous reactivation of latent HIV-1 promoters is linked to the cell cycle as revealed by a genetic-insulators-containing dual-fluorescence HIV-1-based vector. Sci. Rep. 2018, 8, 10204. [CrossRef] [PubMed]

73. Battivelli, E.; Dahabieh, M.S.; Abdel-Mohsen, M.; Svensson, J.P.; Tojal Da Silva, I.; Cohn, L.B.; Gramatica, A.; Deeks, S.; Greene, W.C.; Pillai, S.K.; et al. Distinct chromatin functional states correlate with HIV latency reactivation in infected primary $\mathrm{CD}^{+} \mathrm{T}$ cells. Elife 2018, 7, e34655. [CrossRef] 
74. Lee, S.Y.; Choi, B.-S.; Yoon, C.-H.; Kang, C.; Kim, K.; Kim, K.-C. Selection of biomarkers for HIV-1 latency by integrated analysis. Genomics 2018, in press. [CrossRef]

75. Nishimura, H.; Nose, M.; Hiai, H.; Minato, N.; Honjo, T. Development of lupus-like autoimmune diseases by disruption of the PD-1 gene encoding an ITIM motif-carrying immunoreceptor. Immunity 1999, 11, 141-151. [CrossRef]

76. Nishimura, H.; Okazaki, T.; Tanaka, Y.; Nakatani, K.; Hara, M.; Matsumori, A.; Sasayama, S.; Mizoguchi, A.; Hiai, H.; Minato, N.; et al. Autoimmune dilated cardiomyopathy in PD-1 receptor-deficient mice. Science 2001, 291, 319-322. [CrossRef] [PubMed]

77. Patsoukis, N.; Sari, D.; Boussiotis, V.A. PD-1 inhibits T cell proliferation by upregulating p27 and p15 and suppressing Cdc25A. Cell Cycle 2012, 11, 4305-4309. [CrossRef] [PubMed]

78. D'Souza, M.; Fontenot, A.P.; Mack, D.G.; Lozupone, C.; Dillon, S.; Meditz, A.; Wilson, C.C.; Connick, E.; Palmer, B.E. Programmed death 1 expression on HIV-specific CD4 ${ }^{+} \mathrm{T}$ cells is driven by viral replication and associated with T cell dysfunction. J. Immunol. 2007, 179, 1979-1987. [CrossRef]

79. Kaufmann, D.E.; Kavanagh, D.G.; Pereyra, F.; Zaunders, J.J.; Mackey, E.W.; Miura, T.; Palmer, S.; Brockman, M.; Rathod, A.; Piechocka-Trocha, A.; et al. Upregulation of CTLA-4 by HIV-specific CD4 ${ }^{+}$ $\mathrm{T}$ cells correlates with disease progression and defines a reversible immune dysfunction. Nat. Immunol. 2007, 8, 1246-1254. [CrossRef] [PubMed]

80. Trautmann, L.; Janbazian, L.; Chomont, N.; Said, E.A.; Gimmig, S.; Bessette, B.; Boulassel, M.-R.; Delwart, E.; Sepulveda, H.; Balderas, R.S.; et al. Upregulation of PD-1 expression on HIV-specific CD8 ${ }^{+} \mathrm{T}$ cells leads to reversible immune dysfunction. Nat. Med. 2006, 12, 1198-1202. [CrossRef]

81. Day, C.L.; Kaufmann, D.E.; Kiepiela, P.; Brown, J.A.; Moodley, E.S.; Reddy, S.; Mackey, E.W.; Miller, J.D.; Leslie, A.J.; DePierres, C.; et al. PD-1 expression on HIV-specific T cells is associated with T-cell exhaustion and disease progression. Nature 2006, 443, 350-354. [CrossRef]

82. Evans, V.A.; van der Sluis, R.M.; Solomon, A.; Dantanarayana, A.; McNeil, C.; Garsia, R.; Palmer, S.; Fromentin, R.; Chomont, N.; Sékaly, R.-P.; et al. Programmed cell death-1 contributes to the establishment and maintenance of HIV-1 latency. AIDS 2018, 32, 1491-1497. [CrossRef]

83. Douek, D.C.; Brenchley, J.M.; Betts, M.R.; Ambrozak, D.R.; Hill, B.J.; Okamoto, Y.; Casazza, J.P.; Kuruppu, J.; Kunstman, K.; Wolinsky, S.; et al. HIV preferentially infects HIV-specific CD4 ${ }^{+}$T cells. Nature 2002, 417, 95-98. [CrossRef]

84. Hiener, B.; Horsburgh, B.A.; Eden, J.-S.; Barton, K.; Schlub, T.E.; Lee, E.; von Stockenstrom, S.; Odevall, L.; Milush, J.M.; Liegler, T.; et al. Identification of Genetically Intact HIV-1 Proviruses in Specific CD4 ${ }^{+}$T Cells from Effectively Treated Participants. Cell Rep. 2017, 21, 813-822. [CrossRef]

85. Cuevas, J.M.; Geller, R.; Garijo, R.; López-Aldeguer, J.; Sanjuán, R. Extremely High Mutation Rate of HIV-1 In Vivo. PLoS Biol. 2015, 13, e1002251. [CrossRef] [PubMed]

86. Abram, M.E.; Ferris, A.L.; Shao, W.; Alvord, W.G.; Hughes, S.H. Nature, position, and frequency of mutations made in a single cycle of HIV-1 replication. J. Virol. 2010, 84, 9864-9878. [CrossRef] [PubMed]

87. Harris, R.S.; Bishop, K.N.; Sheehy, A.M.; Craig, H.M.; Petersen-Mahrt, S.K.; Watt, I.N.; Neuberger, M.S.; Malim, M.H. DNA deamination mediates innate immunity to retroviral infection. Cell 2003, 113, 803-809. [CrossRef]

88. Sheehy, A.M.; Gaddis, N.C.; Choi, J.D.; Malim, M.H. Isolation of a human gene that inhibits HIV-1 infection and is suppressed by the viral Vif protein. Nature 2002, 418, 646-650. [CrossRef]

89. Van Opijnen, T.; Boerlijst, M.C.; Berkhout, B. Effects of random mutations in the human immunodeficiency virus type 1 transcriptional promoter on viral fitness in different host cell environments. J. Virol. 2006, 80, 6678-6685. [CrossRef]

90. Kearney, M.F.; Spindler, J.; Shao, W.; Yu, S.; Anderson, E.M.; O'Shea, A.; Rehm, C.; Poethke, C.; Kovacs, N.; Mellors, J.W.; et al. Lack of Detectable HIV-1 Molecular Evolution during Suppressive Antiretroviral Therapy. PLoS Pathog. 2014, 10, e1004010. [CrossRef]

91. Simonetti, F.R.; Sobolewski, M.D.; Fyne, E.; Shao, W.; Spindler, J.; Hattori, J.; Anderson, E.M.; Watters, S.A.; Hill, S.; Wu, X.; et al. Clonally expanded CD4 ${ }^{+} \mathrm{T}$ cells can produce infectious HIV-1 in vivo. Proc. Natl. Acad. Sci. USA 2016, 113, 1883-1888. [CrossRef]

92. Singh, P.K.; Plumb, M.R.; Ferris, A.L.; Iben, J.R.; Wu, X.; Fadel, H.J.; Luke, B.T.; Esnault, C.; Poeschla, E.M.; Hughes, S.H.; et al. LEDGF/p75 interacts with mRNA splicing factors and targets HIV-1 integration to highly spliced genes. Genes Dev. 2015, 29, 2287-2297. [CrossRef] 
93. Wang, G.P.; Ciuffi, A.; Leipzig, J.; Berry, C.C.; Bushman, F.D. HIV integration site selection: Analysis by massively parallel pyrosequencing reveals association with epigenetic modifications. Genome Res. 2007, 17, 1186-1194. [CrossRef]

94. Serrao, E.; Krishnan, L.; Shun, M.-C.; Li, X.; Cherepanov, P.; Engelman, A.; Maertens, G.N. Integrase residues that determine nucleotide preferences at sites of HIV-1 integration: Implications for the mechanism of target DNA binding. Nucleic Acids Res. 2014, 42, 5164-5176. [CrossRef] [PubMed]

95. Demeulemeester, J.; De Rijck, J.; Gijsbers, R.; Debyser, Z. Retroviral integration: Site matters: Mechanisms and consequences of retroviral integration site selection. Bioessays 2015, 37, 1202-1214. [CrossRef] [PubMed]

96. Schröder, A.R.W.; Shinn, P.; Chen, H.; Berry, C.; Ecker, J.R.; Bushman, F. HIV-1 integration in the human genome favors active genes and local hotspots. Cell 2002, 110, 521-529. [CrossRef]

97. Sowd, G.A.; Serrao, E.; Wang, H.; Wang, W.; Fadel, H.J.; Poeschla, E.M.; Engelman, A.N. A critical role for alternative polyadenylation factor CPSF6 in targeting HIV-1 integration to transcriptionally active chromatin. Proc. Natl. Acad. Sci. USA 2016, 113, E1054-E1063. [CrossRef]

98. Marini, B.; Kertesz-Farkas, A.; Ali, H.; Lucic, B.; Lisek, K.; Manganaro, L.; Pongor, S.; Luzzati, R.; Recchia, A.; Mavilio, F.; et al. Nuclear architecture dictates HIV-1 integration site selection. Nature 2015, 521, 227-231. [CrossRef]

99. Albanese, A.; Arosio, D.; Terreni, M.; Cereseto, A. HIV-1 pre-integration complexes selectively target decondensed chromatin in the nuclear periphery. PLoS ONE 2008, 3, e2413. [CrossRef]

100. Eidahl, J.O.; Crowe, B.L.; North, J.A.; McKee, C.J.; Shkriabai, N.; Feng, L.; Plumb, M.; Graham, R.L.; Gorelick, R.J.; Hess, S.; et al. Structural basis for high-affinity binding of LEDGF PWWP to mononucleosomes. Nucleic Acids Res. 2013, 41, 3924-3936. [CrossRef]

101. Sherrill-Mix, S.; Lewinski, M.K.; Famiglietti, M.; Bosque, A.; Malani, N.; Ocwieja, K.E.; Berry, C.C.; Looney, D.; Shan, L.; Agosto, L.M.; et al. HIV latency and integration site placement in five cell-based models. Retrovirology 2013, 10, 90. [CrossRef]

102. Jordan, A.; Bisgrove, D.; Verdin, E. HIV reproducibly establishes a latent infection after acute infection of T cells in vitro. EMBO J. 2003, 22, 1868-1877. [CrossRef]

103. Lenasi, T.; Contreras, X.; Peterlin, B.M. Transcriptional interference antagonizes proviral gene expression to promote HIV latency. Cell Host Microbe 2008, 4, 123-133. [CrossRef]

104. Han, Y.; Lin, Y.B.; An, W.; Xu, J.; Yang, H.-C.; O'Connell, K.; Dordai, D.; Boeke, J.D.; Siliciano, J.D.; Siliciano, R.F. Orientation-dependent regulation of integrated HIV-1 expression by host gene transcriptional readthrough. Cell Host Microbe 2008, 4, 134-146. [CrossRef] [PubMed]

105. Weinberger, L.S.; Burnett, J.C.; Toettcher, J.E.; Arkin, A.P.; Schaffer, D. V Stochastic gene expression in a lentiviral positive-feedback loop: HIV-1 Tat fluctuations drive phenotypic diversity. Cell 2005, 122, 169-182. [CrossRef] [PubMed]

106. Sherrill-Mix, S.; Ocwieja, K.E.; Bushman, F.D. Gene activity in primary T cells infected with HIV89.6: Intron retention and induction of genomic repeats. Retrovirology 2015, 12, 79. [CrossRef] [PubMed]

107. Dlamini, Z.; Hull, R. Can the HIV-1 splicing machinery be targeted for drug discovery? HIV AIDS (Auckl.) 2017, 9, 63-75. [CrossRef]

108. Exline, C.M.; Feng, Z.; Stoltzfus, C.M. Negative and positive mRNA splicing elements act competitively to regulate human immunodeficiency virus type 1 vif gene expression. J. Virol. 2008, 82, 3921-3931. [CrossRef]

109. Tranell, A.; Fenyö, E.M.; Schwartz, S. Serine- and arginine-rich proteins 55 and 75 (SRp55 and SRp75) induce production of HIV-1 vpr mRNA by inhibiting the 5'-splice site of exon 3. J. Biol. Chem. 2010, 285, 31537-31547. [CrossRef]

110. Shkreta, L.; Blanchette, M.; Toutant, J.; Wilhelm, E.; Bell, B.; Story, B.A.; Balachandran, A.; Cochrane, A.; Cheung, P.K.; Harrigan, P.R.; et al. Modulation of the splicing regulatory function of SRSF10 by a novel compound that impairs HIV-1 replication. Nucleic Acids Res. 2017, 45, 4051-4067. [CrossRef]

111. Jacquenet, S.; Méreau, A.; Bilodeau, P.S.; Damier, L.; Stoltzfus, C.M.; Branlant, C. A second exon splicing silencer within human immunodeficiency virus type 1 tat exon 2 represses splicing of Tat mRNA and binds protein hnRNP H. J. Biol. Chem. 2001, 276, 40464-40475. [CrossRef]

112. Asai, K.; Platt, C.; Cochrane, A. Control of HIV-1 env RNA splicing and transport: Investigating the role of hnRNP A1 in exon splicing silencer (ESS3a) function. Virology 2003, 314, 229-242. [CrossRef] 
113. Berro, R.; Kehn, K.; de la Fuente, C.; Pumfery, A.; Adair, R.; Wade, J.; Colberg-Poley, A.M.; Hiscott, J.; Kashanchi, F. Acetylated Tat regulates human immunodeficiency virus type 1 splicing through its interaction with the splicing regulator p32. J. Virol. 2006, 80, 3189-3204. [CrossRef]

114. Baeyens, A.; Naessens, E.; Van Nuffel, A.; Weening, K.E.; Reilly, A.-M.; Claeys, E.; Trypsteen, W.; Vandekerckhove, L.; Eyckerman, S.; Gevaert, K.; et al. HIV-1 Vpr N-terminal tagging affects alternative splicing of the viral genome. Sci. Rep. 2016, 6, 34573. [CrossRef]

115. McLaren, M.; Asai, K.; Cochrane, A. A novel function for Sam68: Enhancement of HIV-1 RNA $3^{\prime}$ end processing. RNA 2004, 10, 1119-1129. [CrossRef]

116. Woolaway, K.; Asai, K.; Emili, A.; Cochrane, A. hnRNP E1 and E2 have distinct roles in modulating HIV-1 gene expression. Retrovirology 2007, 4, 28. [CrossRef]

117. Graf, M.; Bojak, A.; Deml, L.; Bieler, K.; Wolf, H.; Wagner, R. Concerted action of multiple cis-acting sequences is required for Rev dependence of late human immunodeficiency virus type 1 gene expression. J. Virol. 2000, 74, 10822-10826. [CrossRef]

118. Rao, S.; Amorim, R.; Niu, M.; Temzi, A.; Mouland, A.J. The RNA surveillance proteins UPF1, UPF2 and SMG6 affect HIV-1 reactivation at a post-transcriptional level. Retrovirology 2018, 15, 42. [CrossRef]

119. Telwatte, S.; Lee, S.; Somsouk, M.; Hatano, H.; Baker, C.; Kaiser, P.; Kim, P.; Chen, T.-H.; Milush, J.; Hunt, P.W.; et al. Gut and blood differ in constitutive blocks to HIV transcription, suggesting tissue-specific differences in the mechanisms that govern HIV latency. PLoS Pathog. 2018, 14, e1007357. [CrossRef]

120. Yukl, S.A.; Kaiser, P.; Kim, P.; Telwatte, S.; Joshi, S.K.; Vu, M.; Lampiris, H.; Wong, J.K. HIV latency in isolated patient $\mathrm{CD}^{+} \mathrm{T}$ cells may be due to blocks in HIV transcriptional elongation, completion, and splicing. Sci. Transl. Med. 2018, 10, eaap9927. [CrossRef]

121. Golumbeanu, M.; Cristinelli, S.; Rato, S.; Munoz, M.; Cavassini, M.; Beerenwinkel, N.; Ciuffi, A. Single-Cell RNA-Seq Reveals Transcriptional Heterogeneity in Latent and Reactivated HIV-Infected Cells. Cell Rep. 2018, 23, 942-950. [CrossRef]

122. Shan, C.-X.; Qiu, N.-C.; Liu, M.-E.; Zha, S.-L.; Song, X.; Du, Z.-P.; Rao, W.-S.; Jiang, D.-Z.; Zhang, W.; Qiu, M. Effects of Diet on Bile Acid Metabolism and Insulin Resistance in Type 2 Diabetic Rats after Roux-en-Y Gastric Bypass. Obes. Surg. 2018, 28, 3044-3053. [CrossRef]

123. Sarracino, A.; Gharu, L.; Kula, A.; Pasternak, A.O.; Avettand-Fenoel, V.; Rouzioux, C.; Bardina, M.; De Wit, S.; Benkirane, M.; Berkhout, B.; et al. Posttranscriptional Regulation of HIV-1 Gene Expression during Replication and Reactivation from Latency by Nuclear Matrix Protein MATR3. MBio 2018, 9, e02158-18. [CrossRef]

124. Fire, A.; Xu, S.; Montgomery, M.K.; Kostas, S.A.; Driver, S.E.; Mello, C.C. Potent and specific genetic interference by double-stranded RNA in Caenorhabditis elegans. Nature 1998, 391, 806-811. [CrossRef]

125. Hariharan, M.; Scaria, V.; Pillai, B.; Brahmachari, S.K. Targets for human encoded microRNAs in HIV genes. Biochem. Biophys. Res. Commun. 2005, 337, 1214-1218. [CrossRef]

126. Ahluwalia, J.K.; Khan, S.Z.; Soni, K.; Rawat, P.; Gupta, A.; Hariharan, M.; Scaria, V.; Lalwani, M.; Pillai, B.; Mitra, D.; et al. Human cellular microRNA hsa-miR-29a interferes with viral nef protein expression and HIV-1 replication. Retrovirology 2008, 5, 117. [CrossRef] [PubMed]

127. Chiang, K.; Sung, T.-L.; Rice, A.P. Regulation of cyclin T1 and HIV-1 Replication by microRNAs in resting $\mathrm{CD}^{+}$T lymphocytes. J. Virol. 2012, 86, 3244-3252. [CrossRef]

128. Huang, J.; Wang, F.; Argyris, E.; Chen, K.; Liang, Z.; Tian, H.; Huang, W.; Squires, K.; Verlinghieri, G.; Zhang, H. Cellular microRNAs contribute to HIV-1 latency in resting primary CD4 ${ }^{+} \mathrm{T}$ lymphocytes. Nat. Med. 2007, 13, 1241-1247. [CrossRef]

129. Triboulet, R.; Mari, B.; Lin, Y.-L.; Chable-Bessia, C.; Bennasser, Y.; Lebrigand, K.; Cardinaud, B.; Maurin, T.; Barbry, P.; Baillat, V.; et al. Suppression of microRNA-silencing pathway by HIV-1 during virus replication. Science 2007, 315, 1579-1582. [CrossRef]

130. Sung, T.-L.; Rice, A.P. miR-198 inhibits HIV-1 gene expression and replication in monocytes and its mechanism of action appears to involve repression of cyclin T1. PLoS Pathog. 2009, 5, e1000263. [CrossRef]

131. Bennasser, Y.; Le, S.-Y.; Benkirane, M.; Jeang, K.-T. Evidence that HIV-1 encodes an siRNA and a suppressor of RNA silencing. Immunity 2005, 22, 607-619. [CrossRef] [PubMed]

132. Chable-Bessia, C.; Meziane, O.; Latreille, D.; Triboulet, R.; Zamborlini, A.; Wagschal, A.; Jacquet, J.-M.; Reynes, J.; Levy, Y.; Saib, A.; et al. Suppression of HIV-1 replication by microRNA effectors. Retrovirology 2009, 6, 26. [CrossRef] [PubMed] 
133. Omoto, S.; Fujii, Y.R. Regulation of human immunodeficiency virus 1 transcription by nef microRNA. J. Gen. Virol. 2005, 86, 751-755. [CrossRef]

134. Klase, Z.; Kale, P.; Winograd, R.; Gupta, M.V.; Heydarian, M.; Berro, R.; McCaffrey, T.; Kashanchi, F. HIV-1 TAR element is processed by Dicer to yield a viral micro-RNA involved in chromatin remodeling of the viral LTR. BMC Mol. Biol. 2007, 8, 63. [CrossRef] [PubMed]

135. Zhang, Y.; Fan, M.; Geng, G.; Liu, B.; Huang, Z.; Luo, H.; Zhou, J.; Guo, X.; Cai, W.; Zhang, H. A novel HIV-1-encoded microRNA enhances its viral replication by targeting the TATA box region. Retrovirology 2014, 11, 23. [CrossRef]

136. Yeung, M.L.; Bennasser, Y.; Myers, T.G.; Jiang, G.; Benkirane, M.; Jeang, K.-T. Changes in microRNA expression profiles in HIV-1-transfected human cells. Retrovirology 2005, 2, 81. [CrossRef]

137. Nathans, R.; Chu, C.-Y.; Serquina, A.K.; Lu, C.-C.; Cao, H.; Rana, T.M. Cellular microRNA and P bodies modulate host-HIV-1 interactions. Mol. Cell 2009, 34, 696-709. [CrossRef]

138. Reynoso, R.; Laufer, N.; Hackl, M.; Skalicky, S.; Monteforte, R.; Turk, G.; Carobene, M.; Quarleri, J.; Cahn, P.; Werner, R.; et al. MicroRNAs differentially present in the plasma of HIV elite controllers reduce HIV infection in vitro. Sci. Rep. 2014, 4, 5915. [CrossRef] [PubMed]

139. Scarborough, R.J.; Adams, K.L.; Daher, A.; Gatignol, A. Effective inhibition of HIV-1 production by short hairpin RNAs and small interfering RNAs targeting a highly conserved site in HIV-1 Gag RNA is optimized by evaluating alternative length formats. Antimicrob. Agents Chemother. 2015, 59, 5297-5305. [CrossRef] [PubMed]

140. Coburn, G.A.; Cullen, B.R. siRNAs: A new wave of RNA-based therapeutics. J. Antimicrob. Chemother. 2003, 51, 753-756. [CrossRef]

141. Coburn, G.A.; Cullen, B.R. Potent and specific inhibition of human immunodeficiency virus type 1 replication by RNA interference. J. Virol. 2002, 76, 9225-9231. [CrossRef] [PubMed]

142. Bukrinsky, M.I.; Stanwick, T.L.; Dempsey, M.P.; Stevenson, M. Quiescent T lymphocytes as an inducible virus reservoir in HIV-1 infection. Science 1991, 254, 423-427. [CrossRef] [PubMed]

143. Korin, Y.D.; Zack, J.A. Progression to the G1b phase of the cell cycle is required for completion of human immunodeficiency virus type 1 reverse transcription in T cells. J. Virol. 1998, 72, 3161-3168.

144. Budhiraja, S.; Famiglietti, M.; Bosque, A.; Planelles, V.; Rice, A.P. Cyclin T1 and CDK9 T-loop phosphorylation are downregulated during establishment of HIV-1 latency in primary resting memory CD4 ${ }^{+} \mathrm{T}$ cells. J. Virol. 2013, 87, 1211-1220. [CrossRef] [PubMed]

145. Budhiraja, S.; Ramakrishnan, R.; Rice, A.P. Phosphatase PPM1A negatively regulates P-TEFb function in resting CD4(+) T cells and inhibits HIV-1 gene expression. Retrovirology 2012, 9, 52. [CrossRef] [PubMed]

146. Larochelle, S.; Amat, R.; Glover-Cutter, K.; Sansó, M.; Zhang, C.; Allen, J.J.; Shokat, K.M.; Bentley, D.L.; Fisher, R.P. Cyclin-dependent kinase control of the initiation-to-elongation switch of RNA polymerase II. Nat. Struct. Mol. Biol. 2012, 19, 1108-1115. [CrossRef] [PubMed]

147. Stivahtis, G.L.; Soares, M.A.; Vodicka, M.A.; Hahn, B.H.; Emerman, M. Conservation and host specificity of Vpr-mediated cell cycle arrest suggest a fundamental role in primate lentivirus evolution and biology. J. Virol. 1997, 71, 4331-4338.

148. Rogel, M.E.; Wu, L.I.; Emerman, M. The human immunodeficiency virus type 1 vpr gene prevents cell proliferation during chronic infection. J. Virol. 1995, 69, 882-888. [PubMed]

149. Re, F.; Braaten, D.; Franke, E.K.; Luban, J. Human immunodeficiency virus type 1 Vpr arrests the cell cycle in G2 by inhibiting the activation of p34cdc2-cyclin B. J. Virol. 1995, 69, 6859-6864. [PubMed]

150. Gummuluru, S.; Emerman, M. Cell cycle- and Vpr-mediated regulation of human immunodeficiency virus type 1 expression in primary and transformed T-cell lines. J. Virol. 1999, 73, 5422-5430.

151. Goh, W.C.; Rogel, M.E.; Kinsey, C.M.; Michael, S.F.; Fultz, P.N.; Nowak, M.A.; Hahn, B.H.; Emerman, M. HIV-1 Vpr increases viral expression by manipulation of the cell cycle: A mechanism for selection of $\mathrm{Vpr}$ in vivo. Nat. Med. 1998, 4, 65-71. [CrossRef]

152. Shen, A.; Siliciano, J.D.; Pierson, T.C.; Buck, C.B.; Siliciano, R.F. Establishment of latent HIV-1 infection of resting CD4(+) T lymphocytes does not require inactivation of Vpr. Virology 2000, 278, 227-233. [CrossRef]

153. Zahoor, M.A.; Xue, G.; Sato, H.; Murakami, T.; Takeshima, S.; Aida, Y. HIV-1 Vpr induces interferonstimulated genes in human monocyte-derived macrophages. PLoS ONE 2014, 9, e106418. [CrossRef] 
154. Aillet, F.; Masutani, H.; Elbim, C.; Raoul, H.; Chêne, L.; Nugeyre, M.T.; Paya, C.; Barré-Sinoussi, F.; Gougerot-Pocidalo, M.A.; Israël, N. Human immunodeficiency virus induces a dual regulation of Bcl-2, resulting in persistent infection of CD4(+) T- or monocytic cell lines. J. Virol. 1998, 72, 9698-9705. [PubMed]

155. Berro, R.; de la Fuente, C.; Klase, Z.; Kehn, K.; Parvin, L.; Pumfery, A.; Agbottah, E.; Vertes, A.; Nekhai, S.; Kashanchi, F. Identifying the membrane proteome of HIV-1 latently infected cells. J. Biol. Chem. 2007, 282, 8207-8218. [CrossRef] [PubMed]

156. Tan, J.; Wang, X.; Devadas, K.; Zhao, J.; Zhang, P.; Hewlett, I. Some mechanisms of FLIP expression in inhibition of HIV-1 replication in Jurkat cells, CD4 ${ }^{+}$T cells and PBMCs. J. Cell. Physiol. 2013, 228, 2305-2313. [CrossRef] [PubMed]

157. Wang, X.; Ragupathy, V.; Zhao, J.; Hewlett, I. Molecules from apoptotic pathways modulate HIV-1 replication in Jurkat cells. Biochem. Biophys. Res. Commun. 2011, 414, 20-24. [CrossRef]

158. Piette, J.; Legrand-Poels, S. HIV-1 reactivation after an oxidative stress mediated by different reactive oxygen species. Chem. Biol. Interact. 1994, 91, 79-89. [CrossRef]

159. Khan, S.Z.; Hand, N.; Zeichner, S.L. Apoptosis-induced activation of HIV-1 in latently infected cell lines. Retrovirology 2015, 12, 42. [CrossRef] [PubMed]

160. Kuo, H.-H.; Ahmad, R.; Lee, G.Q.; Gao, C.; Chen, H.-R.; Ouyang, Z.; Szucs, M.J.; Kim, D.; Tsibris, A.; Chun, T.-W.; et al. Anti-apoptotic Protein BIRC5 Maintains Survival of HIV-1-Infected CD4 ${ }^{+}$T Cells. Immunity 2018, 48, 1183-1194. [CrossRef] [PubMed]

161. Piekna-Przybylska, D.; Maggirwar, S.B. CD4 ${ }^{+}$memory T cells infected with latent HIV-1 are susceptible to drugs targeting telomeres. Cell Cycle 2018, 17, 2187-2203. [CrossRef]

162. Wagner, T.A.; McLaughlin, S.; Garg, K.; Cheung, C.Y.K.; Larsen, B.B.; Styrchak, S.; Huang, H.C.; Edlefsen, P.T.; Mullins, J.I.; Frenkel, L.M. HIV latency. Proliferation of cells with HIV integrated into cancer genes contributes to persistent infection. Science 2014, 345, 570-573. [CrossRef]

163. Cesana, D.; Santoni de Sio, F.R.; Rudilosso, L.; Gallina, P.; Calabria, A.; Beretta, S.; Merelli, I.; Bruzzesi, E.; Passerini, L.; Nozza, S.; et al. HIV-1-mediated insertional activation of STAT5B and BACH2 trigger viral reservoir in T regulatory cells. Nat. Commun. 2017, 8, 498. [CrossRef]

164. Espert, L.; Varbanov, M.; Robert-Hebmann, V.; Sagnier, S.; Robbins, I.; Sanchez, F.; Lafont, V.; Biard-Piechaczyk, M. Differential role of autophagy in CD4 T cells and macrophages during X4 and R5 HIV-1 infection. PLoS ONE 2009, 4, e5787. [CrossRef] [PubMed]

165. Kyei, G.B.; Dinkins, C.; Davis, A.S.; Roberts, E.; Singh, S.B.; Dong, C.; Wu, L.; Kominami, E.; Ueno, T.; Yamamoto, A.; et al. Autophagy pathway intersects with HIV-1 biosynthesis and regulates viral yields in macrophages. J. Cell Biol. 2009, 186, 255-268. [CrossRef]

166. Sagnier, S.; Daussy, C.F.; Borel, S.; Robert-Hebmann, V.; Faure, M.; Blanchet, F.P.; Beaumelle, B.; Biard-Piechaczyk, M.; Espert, L. Autophagy restricts HIV-1 infection by selectively degrading Tat in CD4 ${ }^{+} \mathrm{T}$ lymphocytes. J. Virol. 2015, 89, 615-625. [CrossRef]

167. Nardacci, R.; Amendola, A.; Ciccosanti, F.; Corazzari, M.; Esposito, V.; Vlassi, C.; Taibi, C.; Fimia, G.M.; Del Nonno, F.; Ippolito, G.; et al. Autophagy plays an important role in the containment of HIV-1 in nonprogressor-infected patients. Autophagy 2014, 10, 1167-1178. [CrossRef] [PubMed]

168. Moore, M.J.; Proudfoot, N.J. Pre-mRNA processing reaches back to transcription and ahead to translation. Cell 2009, 136, 688-700. [CrossRef] [PubMed]

169. Paz, S.; Krainer, A.R.; Caputi, M. HIV-1 transcription is regulated by splicing factor SRSF1. Nucleic Acids Res. 2014, 42, 13812-13823. [CrossRef]

170. Mueller, N.; Pasternak, A.O.; Klaver, B.; Cornelissen, M.; Berkhout, B.; Das, A.T. The HIV-1 Tat Protein Enhances Splicing at the Major Splice Donor Site. J. Virol. 2018, 92, e01855-17. [CrossRef]

171. Bohne, J.; Schambach, A.; Zychlinski, D. New way of regulating alternative splicing in retroviruses: The promoter makes a difference. J. Virol. 2007, 81, 3652-3656. [CrossRef] [PubMed]

172. Li, G.; De Clercq, E. HIV Genome-Wide Protein Associations: A Review of 30 Years of Research. Microbiol. Mol. Biol. Rev. 2016, 80, 679-731. [CrossRef]

173. Wilhelm, E.; Bell, B. Selective recognition of viral promoters by host cell transcription complexes: Challenges and opportunities to control latency. Curr. Opin. Virol. 2013, 3, 380-386. [CrossRef]

174. Dahabieh, M.S.; Ooms, M.; Malcolm, T.; Simon, V.; Sadowski, I. Identification and functional analysis of a second RBF-2 binding site within the HIV-1 promoter. Virology 2011, 418, 57-66. [CrossRef] [PubMed] 
175. Wilhelm, E.; Doyle, M.-C.; Nzaramba, I.; Magdzinski, A.; Dumais, N.; Bell, B. CTGC motifs within the HIV core promoter specify Tat-responsive pre-initiation complexes. Retrovirology 2012, 9, 62. [CrossRef] [PubMed]

176. Pereira, L.A.; Bentley, K.; Peeters, A.; Churchill, M.J.; Deacon, N.J. A compilation of cellular transcription factor interactions with the HIV-1 LTR promoter. Nucleic Acids Res. 2000, 28, 663-668. [CrossRef] [PubMed]

177. Taube, R.; Peterlin, M. Lost in transcription: Molecular mechanisms that control HIV latency. Viruses 2013, 5, 902-927. [CrossRef]

178. Hultquist, J.F.; Schumann, K.; Woo, J.M.; Manganaro, L.; McGregor, M.J.; Doudna, J.; Simon, V.; Krogan, N.J.; Marson, A. A Cas9 Ribonucleoprotein Platform for Functional Genetic Studies of HIV-Host Interactions in Primary Human T Cells. Cell Rep. 2016, 17, 1438-1452. [CrossRef] [PubMed]

179. Wilhelm, E.; Takacs, C.; Bell, B. Probing endogenous RNA polymerase II pre-initiation complexes by electrophoretic mobility shift assay. Methods Mol. Biol. 2012, 809, 63-74.

180. Sainsbury, S.; Bernecky, C.; Cramer, P. Structural basis of transcription initiation by RNA polymerase II. Nat. Rev. Mol. Cell Biol. 2015, 16, 129-143. [CrossRef]

181. Basehoar, A.D.; Zanton, S.J.; Pugh, B.F.F. Identification and Distinct Regulation of Yeast TATA Box-Containing Genes. Cell 2004, 116, 699-709. [CrossRef]

182. Xiao, H.; Lis, J.T.; Jeang, K.T. Promoter activity of Tat at steps subsequent to TATA-binding protein recruitment. Mol. Cell. Biol. 1997, 17, 6898-6905. [CrossRef]

183. van Opijnen, T.; Kamoschinski, J.; Jeeninga, R.E.; Berkhout, B. The human immunodeficiency virus type 1 promoter contains a CATA box instead of a TATA box for optimal transcription and replication. J. Virol. 2004, 78, 6883-6890. [CrossRef]

184. Kashanchi, F.; Khleif, S.N.; Duvall, J.F.; Sadaie, M.R.; Radonovich, M.F.; Cho, M.; Martin, M.A.; Chen, S.Y.; Weinmann, R.; Brady, J.N. Interaction of human immunodeficiency virus type 1 Tat with a unique site of TFIID inhibits negative cofactor Dr1 and stabilizes the TFIID-TFIIA complex. J. Virol. 1996, 70, 5503-5510. [PubMed]

185. Veschambre, P.; Roisin, A.; Jalinot, P. Biochemical and functional interaction of the human immunodeficiency virus type 1 Tat transactivator with the general transcription factor TFIIB. J. Gen. Virol. 1997, 78 Pt 9 , 2235-2245. [CrossRef]

186. Fairley, J.A.; Evans, R.; Hawkes, N.A.; Roberts, S.G.E. Core promoter-dependent TFIIB conformation and a role for TFIIB conformation in transcription start site selection. Mol. Cell. Biol. 2002, 22, 6697-6705. [CrossRef] [PubMed]

187. Zhou, M.; Kashanchi, F.; Jiang, H.; Ge, H.; Brady, J.N. Phosphorylation of the RAP74 subunit of TFIIF correlates with Tat-activated transcription of the HIV-1 long terminal repeat. Virology 2000, 268, 452-460. [CrossRef] [PubMed]

188. Abbott, K.L.; Archambault, J.; Xiao, H.; Nguyen, B.D.; Roeder, R.G.; Greenblatt, J.; Omichinski, J.G.; Legault, P. Interactions of the HIV-1 Tat and RAP74 proteins with the RNA polymerase II CTD phosphatase FCP1. Biochemistry 2005, 44, 2716-2731. [CrossRef] [PubMed]

189. Parada, C.A.; Roeder, R.G. Enhanced processivity of RNA polymerase II triggered by Tat-induced phosphorylation of its carboxy-terminal domain. Nature 1996, 384, 375-378. [CrossRef]

190. Kim, Y.K.; Bourgeois, C.F.; Pearson, R.; Tyagi, M.; West, M.J.; Wong, J.; Wu, S.-Y.; Chiang, C.-M.; Karn, J. Recruitment of TFIIH to the HIV LTR is a rate-limiting step in the emergence of HIV from latency. EMBO J. 2006, 25, 3596-3604. [CrossRef] [PubMed]

191. Bell, B.; Tora, L. Regulation of gene expression by multiple forms of TFIID and other novel TAFII-containing complexes. Exp. Cell Res. 1999, 246, 11-19. [CrossRef] [PubMed]

192. Raha, T.; Cheng, S.W.G.; Green, M.R. HIV-1 Tat stimulates transcription complex assembly through recruitment of TBP in the absence of TAFs. PLoS Biol. 2005, 3, e44. [CrossRef]

193. Berkhout, B.; Jeang, K.T. Functional roles for the TATA promoter and enhancers in basal and Tat-induced expression of the human immunodeficiency virus type 1 long terminal repeat. J. Virol. 1992, 66, 139-149.

194. Eilebrecht, S.; Benecke, B.-J.; Benecke, A.G. Latent HIV-1 TAR Regulates 7SK-responsive P-TEFb Target Genes and Targets Cellular Immune Responses in the Absence of Tat. Genom. Proteom. Bioinform. 2017, 15, 313-323. [CrossRef] [PubMed]

195. Narita, T.; Yamaguchi, Y.; Yano, K.; Sugimoto, S.; Chanarat, S.; Wada, T.; Kim, D.; Hasegawa, J.; Omori, M.; Inukai, N.; et al. Human transcription elongation factor NELF: Identification of novel subunits and reconstitution of the functionally active complex. Mol. Cell. Biol. 2003, 23, 1863-1873. [CrossRef] 
196. Egloff, S.; Vitali, P.; Tellier, M.; Raffel, R.; Murphy, S.; Kiss, T. The 7SK snRNP associates with the little elongation complex to promote snRNA gene expression. EMBO J. 2017, 36, 934-948. [CrossRef] [PubMed]

197. Mousseau, G.; Valente, S.T. Role of Host Factors on the Regulation of Tat-Mediated HIV-1 Transcription. Curr. Pharm. Des. 2017, 23, 4079-4090. [CrossRef]

198. Bartholomeeusen, K.; Xiang, Y.; Fujinaga, K.; Peterlin, B.M. Bromodomain and extra-terminal (BET) bromodomain inhibition activate transcription via transient release of positive transcription elongation factor b (P-TEFb) from 7SK small nuclear ribonucleoprotein. J. Biol. Chem. 2012, 287, 36609-36616. [CrossRef]

199. Zhu, J.; Gaiha, G.D.; John, S.P.; Pertel, T.; Chin, C.R.; Gao, G.; Qu, H.; Walker, B.D.; Elledge, S.J.; Brass, A.L. Reactivation of latent HIV-1 by inhibition of BRD4. Cell Rep. 2012, 2, 807-816. [CrossRef] [PubMed]

200. Li, Z.; Guo, J.; Wu, Y.; Zhou, Q. The BET bromodomain inhibitor JQ1 activates HIV latency through antagonizing Brd4 inhibition of Tat-transactivation. Nucleic Acids Res. 2013, 41, 277-287. [CrossRef] [PubMed]

201. Abner, E.; Stoszko, M.; Zeng, L.; Chen, H.-C.; Izquierdo-Bouldstridge, A.; Konuma, T.; Zorita, E.; Fanunza, E.; Zhang, Q.; Mahmoudi, T.; et al. A New Quinoline BRD4 Inhibitor Targets a Distinct Latent HIV-1 Reservoir for Reactivation from Other "Shock" Drugs. J. Virol. 2018, 92, e02056-17. [CrossRef]

202. Eilebrecht, S.; Brysbaert, G.; Wegert, T.; Urlaub, H.; Benecke, B.-J.; Benecke, A. 7SK small nuclear RNA directly affects HMGA1 function in transcription regulation. Nucleic Acids Res. 2011, 39, 2057-2072. [CrossRef] [PubMed]

203. Eilebrecht, S.; Wilhelm, E.; Benecke, B.-J.; Bell, B.; Benecke, A.G. HMGA1 directly interacts with TAR to modulate basal and Tat-dependent HIV transcription. RNA Biol. 2013, 10, 436-444. [CrossRef] [PubMed]

204. Estable, M.C.; Naghavi, M.H.; Kato, H.; Xiao, H.; Qin, J.; Vahlne, A.; Roeder, R.G. MCEF, the newest member of the AF4 family of transcription factors involved in leukemia, is a positive transcription elongation factor-b-associated protein. J. Biomed. Sci. 2002, 9, 234-245. [CrossRef] [PubMed]

205. He, N.; Liu, M.; Hsu, J.; Xue, Y.; Chou, S.; Burlingame, A.; Krogan, N.J.; Alber, T.; Zhou, Q. HIV-1 Tat and host AFF4 recruit two transcription elongation factors into a bifunctional complex for coordinated activation of HIV-1 transcription. Mol. Cell 2010, 38, 428-438. [CrossRef]

206. Sobhian, B.; Laguette, N.; Yatim, A.; Nakamura, M.; Levy, Y.; Kiernan, R.; Benkirane, M. HIV-1 Tat assembles a multifunctional transcription elongation complex and stably associates with the 7SK snRNP. Mol. Cell 2010, 38, 439-451. [CrossRef]

207. Schulze-Gahmen, U.; Upton, H.; Birnberg, A.; Bao, K.; Chou, S.; Krogan, N.J.; Zhou, Q.; Alber, T. The AFF4 scaffold binds human P-TEFb adjacent to HIV Tat. Elife 2013, 2, e00327. [CrossRef] [PubMed]

208. Chou, S.; Upton, H.; Bao, K.; Schulze-Gahmen, U.; Samelson, A.J.; He, N.; Nowak, A.; Lu, H.; Krogan, N.J.; Zhou, Q.; et al. HIV-1 Tat recruits transcription elongation factors dispersed along a flexible AFF4 scaffold. Proc. Natl. Acad. Sci. USA 2013, 110, E123-E131. [CrossRef] [PubMed]

209. He, N.; Chan, C.K.; Sobhian, B.; Chou, S.; Xue, Y.; Liu, M.; Alber, T.; Benkirane, M.; Zhou, Q. Human Polymerase-Associated Factor complex (PAFc) connects the Super Elongation Complex (SEC) to RNA polymerase II on chromatin. Proc. Natl. Acad. Sci. USA 2011, 108, E636-E645. [CrossRef]

210. Schulze-Gahmen, U.; Echeverria, I.; Stjepanovic, G.; Bai, Y.; Lu, H.; Schneidman-Duhovny, D.; Doudna, J.A.; Zhou, Q.; Sali, A.; Hurley, J.H. Insights into HIV-1 proviral transcription from integrative structure and dynamics of the Tat:AFF4:P-TEFb:TAR complex. Elife 2016, 5, e15910. [CrossRef] [PubMed]

211. Qi, S.; Li, Z.; Schulze-Gahmen, U.; Stjepanovic, G.; Zhou, Q.; Hurley, J.H. Structural basis for ELL2 and AFF4 activation of HIV-1 proviral transcription. Nat. Commun. 2017, 8, 14076. [CrossRef] [PubMed]

212. Li, Z.; Lu, H.; Zhou, Q. A Minor Subset of Super Elongation Complexes Plays a Predominant Role in Reversing HIV-1 Latency. Mol. Cell. Biol. 2016, 36, 1194-1205. [CrossRef]

213. Wu, J.; Ao, M.; Shao, R.; Wang, H.; Yu, D.; Fang, M.; Gao, X.; Wu, Z.; Zhou, Q.; Xue, Y. A chalcone derivative reactivates latent HIV-1 transcription through activating P-TEFb and promoting Tat-SEC interaction on viral promoter. Sci. Rep. 2017, 7, 10657. [CrossRef]

214. Niedzielski, M.F.; Hopewell, R.; Ismail, Z.; Estable, M.C. MCEF is localized to the nucleus by protein sequences encoded within three distinct exons, where it represses HIV-1 Tat-transactivation of LTR-directed transcription. Int. J. Biol. Sci. 2007, 3, 225-236. [CrossRef] [PubMed]

215. Lin, C.; Garrett, A.S.; De Kumar, B.; Smith, E.R.; Gogol, M.; Seidel, C.; Krumlauf, R.; Shilatifard, A. Dynamic transcriptional events in embryonic stem cells mediated by the super elongation complex (SEC). Genes Dev. 2011, 25, 1486-1498. [CrossRef] 
216. Takahashi, H.; Parmely, T.J.; Sato, S.; Tomomori-Sato, C.; Banks, C.A.S.; Kong, S.E.; Szutorisz, H.; Swanson, S.K.; Martin-Brown, S.; Washburn, M.P.; et al. Human mediator subunit MED26 functions as a docking site for transcription elongation factors. Cell 2011, 146, 92-104. [CrossRef] [PubMed]

217. Yadav, D.; Ghosh, K.; Basu, S.; Roeder, R.G.; Biswas, D. Multivalent Role of Human TFIID in Recruiting Elongation Components at the Promoter-Proximal Region for Transcriptional Control. Cell Rep. 2019, 26, 1303-1317. [CrossRef] [PubMed]

218. Taki, T.; Kano, H.; Taniwaki, M.; Sako, M.; Yanagisawa, M.; Hayashi, Y. AF5q31, a newly identified AF4-related gene, is fused to MLL in infant acute lymphoblastic leukemia with ins(5;11)(q31;q13q23). Proc. Natl. Acad. Sci. USA 1999, 96, 14535-14540. [CrossRef] [PubMed]

219. Vijayalingam, S.; Chinnadurai, G. Adenovirus L-E1A activates transcription through mediator complex-dependent recruitment of the super elongation complex. J. Virol. 2013, 87, 3425-3434. [CrossRef]

220. Luo, Z.; Lin, C.; Guest, E.; Garrett, A.S.; Mohaghegh, N.; Swanson, S.; Marshall, S.; Florens, L.; Washburn, M.P.; Shilatifard, A. The super elongation complex family of RNA polymerase II elongation factors: Gene target specificity and transcriptional output. Mol. Cell. Biol. 2012, 32, 2608-2617. [CrossRef]

221. Dolcet, X.; Llobet, D.; Pallares, J.; Matias-Guiu, X. NF-kB in development and progression of human cancer. Virchows Arch. 2005, 446, 475-482. [CrossRef]

222. Ne, E.; Palstra, R.-J.; Mahmoudi, T. Transcription: Insights from the HIV-1 Promoter. Int. Rev. Cell Mol. Biol. 2018, 335, 191-243.

223. Sadowski, I.; Lourenco, P.; Malcolm, T. Factors controlling chromatin organization and nucleosome positioning for establishment and maintenance of HIV latency. Curr. HIV Res. 2008, 6, 286-295. [CrossRef]

224. Zhang, L.; Huang, Y.; Yuan, H.; Chen, B.K.; Ip, J.; Ho, D.D. Identification of a replication-competent pathogenic human immunodeficiency virus type 1 with a duplication in the TCF-1alpha region but lacking NF-kappaB binding sites. J. Virol. 1997, 71, 1651-1656. [PubMed]

225. Chae, C.-S.; Kim, G.-C.; Park, E.S.; Lee, C.-G.; Verma, R.; Cho, H.-L.; Jun, C.-D.; Yoo, Y.J.; Im, S.-H. NFAT1 Regulates Systemic Autoimmunity through the Modulation of a Dendritic Cell Property. J. Immunol. 2017, 199, 3051-3062. [CrossRef] [PubMed]

226. Giffin, M.J.; Stroud, J.C.; Bates, D.L.; von Koenig, K.D.; Hardin, J.; Chen, L. Structure of NFAT1 bound as a dimer to the HIV-1 LTR kappa B element. Nat. Struct. Biol. 2003, 10, 800-806. [CrossRef]

227. Jones, K.A.; Kadonaga, J.T.; Luciw, P.A.; Tjian, R. Activation of the AIDS retrovirus promoter by the cellular transcription factor, Sp1. Science 1986, 232, 755-759. [CrossRef]

228. Sadowski, I.; Mitchell, D.A. TFII-I and USF (RBF-2) regulate Ras/MAPK-responsive HIV-1 transcription in T cells. Eur. J. Cancer 2005, 41, 2528-2536. [CrossRef]

229. Bell, B.; Sadowski, I. Ras-responsiveness of the HIV-1 LTR requires RBF-1 and RBF-2 binding sites. Oncogene 1996, 13, 2687-2697.

230. Estable, M.C.; Bell, B.; Hirst, M.; Sadowski, I. Naturally occurring human immunodeficiency virus type 1 long terminal repeats have a frequently observed duplication that binds RBF-2 and represses transcription. J. Virol. 1998, 72, 6465-6474.

231. Estable, M.C.; Bell, B.; Merzouki, A.; Montaner, J.S.; O’Shaughnessy, M.V.; Sadowski, I.J. Human immunodeficiency virus type 1 long terminal repeat variants from 42 patients representing all stages of infection display a wide range of sequence polymorphism and transcription activity. J. Virol. 1996, 70, 4053-4062.

232. Chen, J.; Malcolm, T.; Estable, M.C.; Roeder, R.G.; Sadowski, I. TFII-I regulates induction of chromosomally integrated human immunodeficiency virus type 1 long terminal repeat in cooperation with USF. J. Virol. 2005, 79, 4396-4406. [CrossRef]

233. Malcolm, T.; Kam, J.; Pour, P.S.; Sadowski, I. Specific interaction of TFII-I with an upstream element on the HIV-1 LTR regulates induction of latent provirus. FEBS Lett. 2008, 582, 3903-3908. [CrossRef]

234. Malcolm, T.; Chen, J.; Chang, C.; Sadowski, I. Induction of chromosomally integrated HIV-1 LTR requires RBF-2 (USF/TFII-I) and Ras/MAPK signaling. Virus Genes 2007, 35, 215-223. [CrossRef] [PubMed]

235. Estable, M.C. In search of a function for the most frequent naturally-occurring length polymorphism (MFNLP) of the HIV-1 LTR: Retaining functional coupling, of Nef and RBF-2, at RBEIII? Int. J. Biol. Sci. 2007, 3, 318-327. [CrossRef] [PubMed]

236. Kao, SY.; Calman, AF.; Luciw, PA. Peterlin, Anti-termination of transcription within the long terminal repeat of HIV-1 by tat gene product. Nature. 1987, 330, 489-493. [CrossRef] [PubMed] 
237. Ensoli, B.; Barillari, G.; Salahuddin, S.Z.; Gallo, R.C.; Wong-Staal, F. Tat protein of HIV-1 stimulates growth of cells derived from Kaposi's sarcoma lesions of AIDS patients. Nature 1990, 345, 84-86. [CrossRef] [PubMed]

238. Demarchi, F.; d'Adda di Fagagna, F.; Falaschi, A.; Giacca, M. Activation of transcription factor NF-kappaB by the Tat protein of human immunodeficiency virus type 1. J. Virol. 1996, 70, 4427-4437. [PubMed]

239. Li, L.; Li, H.S.; Pauza, C.D.; Bukrinsky, M.; Zhao, R.Y. Roles of HIV-1 auxiliary proteins in viral pathogenesis and host-pathogen interactions. Cell Res. 2005, 15, 923-934. [CrossRef]

240. Liu, R.; Lin, Y.; Jia, R.; Geng, Y.; Liang, C.; Tan, J.; Qiao, W. HIV-1 Vpr stimulates NF-kB and AP-1 signaling by activating TAK1. Retrovirology 2014, 11, 45. [CrossRef]

241. Hütter, G.; Nowak, D.; Mossner, M.; Ganepola, S.; Müssig, A.; Allers, K.; Schneider, T.; Hofmann, J.; Kücherer, C.; Blau, O.; et al. Long-term control of HIV by CCR5 Delta32/Delta32 stem-cell transplantation. N. Engl. J. Med. 2009, 360, 692-698. [CrossRef]

242. Sáez-Cirión, A.; Bacchus, C.; Hocqueloux, L.; Avettand-Fenoel, V.; Girault, I.; Lecuroux, C.; Potard, V.; Versmisse, P.; Melard, A.; Prazuck, T.; et al. Post-treatment HIV-1 controllers with a long-term virological remission after the interruption of early initiated antiretroviral therapy ANRS VISCONTI Study. PLoS Pathog. 2013, 9, e1003211. [CrossRef] [PubMed]

243. Ishino, Y.; Shinagawa, H.; Makino, K.; Amemura, M.; Nakata, A. Nucleotide sequence of the iap gene, responsible for alkaline phosphatase isozyme conversion in Escherichia coli, and identification of the gene product. J. Bacteriol. 1987, 169, 5429-5433. [CrossRef]

244. Wang, Z.; Pan, Q.; Gendron, P.; Zhu, W.; Guo, F.; Cen, S.; Wainberg, M.A.; Liang, C. CRISPR/Cas9-Derived Mutations Both Inhibit HIV-1 Replication and Accelerate Viral Escape. Cell Rep. 2016, 15, 481-489. [CrossRef] [PubMed]

245. Wang, G.; Zhao, N.; Berkhout, B.; Das, A.T. A Combinatorial CRISPR-Cas9 Attack on HIV-1 DNA Extinguishes All Infectious Provirus in Infected T Cell Cultures. Cell Rep. 2016, 17, 2819-2826. [CrossRef] [PubMed]

246. Wang, G.; Zhao, N.; Berkhout, B.; Das, A.T. CRISPR-Cas based antiviral strategies against HIV-1. Virus Res. 2018, 244, 321-332. [CrossRef] [PubMed]

247. Koup, R.A.; Safrit, J.T.; Cao, Y.; Andrews, C.A.; McLeod, G.; Borkowsky, W.; Farthing, C.; Ho, D.D. Temporal association of cellular immune responses with the initial control of viremia in primary human immunodeficiency virus type 1 syndrome. J. Virol. 1994, 68, 4650-4655. [PubMed]

248. Schmitz, J.E.; Kuroda, M.J.; Santra, S.; Sasseville, V.G.; Simon, M.A.; Lifton, M.A.; Racz, P.; Tenner-Racz, K.; Dalesandro, M.; Scallon, B.J.; et al. Control of viremia in simian immunodeficiency virus infection by CD8 ${ }^{+}$ lymphocytes. Science 1999, 283, 857-860. [CrossRef]

249. McBrien, J.B.; Kumar, N.A.; Silvestri, G. Mechanisms of CD8 ${ }^{+}$T cell-mediated suppression of HIV/SIV replication. Eur. J. Immunol. 2018, 48, 898-914. [CrossRef]

250. Cartwright, E.K.; Spicer, L.; Smith, S.A.; Lee, D.; Fast, R.; Paganini, S.; Lawson, B.O.; Nega, M.; Easley, K.; Schmitz, J.E.; et al. CD8(+) Lymphocytes Are Required for Maintaining Viral Suppression in SIV-Infected Macaques Treated with Short-Term Antiretroviral Therapy. Immunity 2016, 45, 656-668. [CrossRef]

251. Cao, Y.; Cartwright, E.K.; Silvestri, G.; Perelson, A.S. CD8 ${ }^{+}$lymphocyte control of SIV infection during antiretroviral therapy. PLoS Pathog. 2018, 14, e1007350. [CrossRef]

252. Kuhlmann, A.-S.; Peterson, C.W.; Kiem, H.-P. Chimeric antigen receptor T-cell approaches to HIV cure. Curr. Opin. HIV AIDS 2018, 13, 446-453. [CrossRef]

253. Wagner, T.A. Quarter Century of Anti-HIV CAR T Cells. Curr. HIV/AIDS Rep. 2018, 15, 147-154. [CrossRef]

254. Riddell, S.R.; Elliott, M.; Lewinsohn, D.A.; Gilbert, M.J.; Wilson, L.; Manley, S.A.; Lupton, S.D.; Overell, R.W.; Reynolds, T.C.; Corey, L.; et al. T-cell mediated rejection of gene-modified HIV-specific cytotoxic T lymphocytes in HIV-infected patients. Nat. Med. 1996, 2, 216-223. [CrossRef] [PubMed]

255. Zhen, A.; Peterson, C.W.; Carrillo, M.A.; Reddy, S.S.; Youn, C.S.; Lam, B.B.; Chang, N.Y.; Martin, H.A.; Rick, J.W.; Kim, J.; et al. Long-term persistence and function of hematopoietic stem cell-derived chimeric antigen receptor T cells in a nonhuman primate model of HIV/AIDS. PLoS Pathog. 2017, 13, e1006753. [CrossRef] [PubMed]

256. Maude, S.L.; Frey, N.; Shaw, P.A.; Aplenc, R.; Barrett, D.M.; Bunin, N.J.; Chew, A.; Gonzalez, V.E.; Zheng, Z.; Lacey, S.F.; et al. Chimeric antigen receptor T cells for sustained remissions in leukemia. N. Engl. J. Med. 2014, 371, 1507-1517. [CrossRef] [PubMed] 
257. Carrillo, J.; Clotet, B.; Blanco, J. Antibodies and Antibody Derivatives: New Partners in HIV Eradication Strategies. Front. Immunol. 2018, 9, 2429. [CrossRef] [PubMed]

258. Bar-On, Y.; Gruell, H.; Schoofs, T.; Pai, J.A.; Nogueira, L.; Butler, A.L.; Millard, K.; Lehmann, C.; Suárez, I.; Oliveira, T.Y.; et al. Safety and antiviral activity of combination HIV-1 broadly neutralizing antibodies in viremic individuals. Nat. Med. 2018, 24, 1701-1707. [CrossRef] [PubMed]

259. Nishimura, Y.; Gautam, R.; Chun, T.-W.; Sadjadpour, R.; Foulds, K.E.; Shingai, M.; Klein, F.; Gazumyan, A.; Golijanin, J.; Donaldson, M.; et al. Early antibody therapy can induce long-lasting immunity to SHIV. Nature 2017, 543, 559-563. [CrossRef] [PubMed]

260. Mendoza, P.; Gruell, H.; Nogueira, L.; Pai, J.A.; Butler, A.L.; Millard, K.; Lehmann, C.; Suárez, I.; Oliveira, T.Y.; Lorenzi, J.C.C.; et al. Combination therapy with anti-HIV-1 antibodies maintains viral suppression. Nature 2018, 561, 479-484. [CrossRef]

261. Fabozzi, G.; Pegu, A.; Koup, R.A.; Petrovas, C. Bispecific antibodies: Potential immunotherapies for HIV treatment. Methods 2019, 154, 118-124. [CrossRef]

262. Padte, N.N.; Yu, J.; Huang, Y.; Ho, D.D. Engineering multi-specific antibodies against HIV-1. Retrovirology 2018, 15, 60. [CrossRef]

263. Pace, C.S.; Song, R.; Ochsenbauer, C.; Andrews, C.D.; Franco, D.; Yu, J.; Oren, D.A.; Seaman, M.S.; Ho, D.D. Bispecific antibodies directed to CD4 domain 2 and HIV envelope exhibit exceptional breadth and picomolar potency against HIV-1. Proc. Natl. Acad. Sci. USA 2013, 110, 13540-13545. [CrossRef]

264. Pegu, A.; Asokan, M.; Wu, L.; Wang, K.; Hataye, J.; Casazza, J.P.; Guo, X.; Shi, W.; Georgiev, I.; Zhou, T.; et al. Activation and lysis of human CD4 cells latently infected with HIV-1. Nat. Commun. 2015, 6, 8447. [CrossRef] [PubMed]

265. Huang, Y.; Yu, J.; Lanzi, A.; Yao, X.; Andrews, C.D.; Tsai, L.; Gajjar, M.R.; Sun, M.; Seaman, M.S.; Padte, N.N.; et al. Engineered Bispecific Antibodies with Exquisite HIV-1-Neutralizing Activity. Cell 2016, 165, 1621-1631. [CrossRef] [PubMed]

266. Bournazos, S.; Gazumyan, A.; Seaman, M.S.; Nussenzweig, M.C.; Ravetch, J. V Bispecific Anti-HIV-1 Antibodies with Enhanced Breadth and Potency. Cell 2016, 165, 1609-1620. [CrossRef]

267. Xu, L.; Pegu, A.; Rao, E.; Doria-Rose, N.; Beninga, J.; McKee, K.; Lord, D.M.; Wei, R.R.; Deng, G.; Louder, M.; et al. Trispecific broadly neutralizing HIV antibodies mediate potent SHIV protection in macaques. Science 2017, 358, 85-90. [CrossRef]

268. Sloan, D.D.; Lam, C.-Y.K.; Irrinki, A.; Liu, L.; Tsai, A.; Pace, C.S.; Kaur, J.; Murry, J.P.; Balakrishnan, M.; Moore, P.A.; et al. Targeting HIV Reservoir in Infected CD4 T Cells by Dual-Affinity Re-targeting Molecules (DARTs) that Bind HIV Envelope and Recruit Cytotoxic T Cells. PLoS Pathog. 2015, 11, e1005233. [CrossRef] [PubMed]

269. Sung, J.A.M.; Pickeral, J.; Liu, L.; Stanfield-Oakley, S.A.; Lam, C.-Y.K.; Garrido, C.; Pollara, J.; LaBranche, C.; Bonsignori, M.; Moody, M.A.; et al. Dual-Affinity Re-Targeting proteins direct T cell-mediated cytolysis of latently HIV-infected cells. J. Clin. Investig. 2015, 125, 4077-4090. [CrossRef] [PubMed]

270. Garcia, J.V.; Miller, A.D. Serine phosphorylation-independent downregulation of cell-surface CD4 by nef. Nature 1991, 350, 508-511. [CrossRef]

271. Desrosiers, R.C. Strategies used by human immunodeficiency virus that allow persistent viral replication. Nat. Med. 1999, 5, 723-725. [CrossRef] [PubMed]

272. Goulder, P.; Deeks, S.G. HIV control: Is getting there the same as staying there? PLoS Pathog. 2018, 14, e1007222. [CrossRef] [PubMed]

273. Olson, A.D.; Meyer, L.; Prins, M.; Thiebaut, R.; Gurdasani, D.; Guiguet, M.; Chaix, M.-L.; Amornkul, P.; Babiker, A.; Sandhu, M.S.; et al. An evaluation of HIV elite controller definitions within a large seroconverter cohort collaboration. PLoS ONE 2014, 9, e86719. [CrossRef]

274. Ilyinskii, P.O.; Simon, M.A.; Czajak, S.C.; Lackner, A.A.; Desrosiers, R.C. Induction of AIDS by simian immunodeficiency virus lacking NF-kappaB and SP1 binding elements. J. Virol. 1997, 71, 1880-1887.

275. Blancou, P.; Chenciner, N.; Cumont, M.C.; Wain-Hobson, S.; Hurtrel, B.; Cheynier, R. The infiltration kinetics of simian immunodeficiency virus-specific T cells drawn to sites of high antigenic stimulation determines local in vivo viral escape. Proc. Natl. Acad. Sci. USA 2001, 98, 13237-13242. [CrossRef] [PubMed]

276. Blazek, D.; Teque, F.; Mackewicz, C.; Peterlin, M.; Levy, J.A. The CD8 ${ }^{+}$cell non-cytotoxic antiviral response affects RNA polymerase II-mediated human immunodeficiency virus transcription in infected CD4 ${ }^{+}$cells. J. Gen. Virol. 2016, 97, 220-224. [CrossRef] [PubMed] 
277. Shridhar, V.; Chen, Y.; Gupta, P. The CD8 antiviral factor (CAF) can suppress HIV-1 transcription from the long terminal repeat (LTR) promoter in the absence of elements upstream of the CATATAA box. Virol. J. 2014, 11, 130. [CrossRef]

278. Jean, M.J.; Fiches, G.; Hayashi, T.; Zhu, J. Current Strategies for Elimination of HIV-1 Latent Reservoirs Using Chemical Compounds Targeting Host and Viral Factors. AIDS Res. Hum. Retrovir. 2019, 35, 1-24. [CrossRef] [PubMed]

279. Darcis, G.; Das, A.T.; Berkhout, B. Tackling HIV Persistence: Pharmacological versus CRISPR-Based Shock Strategies. Viruses 2018, 10, 157. [CrossRef]

280. Kim, Y.; Anderson, J.L.; Lewin, S.R. Getting the "Kill" into "Shock and Kill": Strategies to Eliminate Latent HIV. Cell Host Microbe 2018, 23, 14-26. [CrossRef] [PubMed]

281. Spivak, A.M.; Planelles, V. Novel Latency Reversal Agents for HIV-1 Cure. Annu. Rev. Med. 2018, 69, 421-436. [CrossRef]

282. Imperial College of London. Wighton Kate First Randomized Trial of "Kick and Kill" Approach to HIV Cure Leaves Puzzles to Be Solved-ScienceDaily. Available online: https:/ /www.sciencedaily.com/releases / 2018/07/180724110046.htm (accessed on 12 December 2018).

283. Moron-Lopez, S.; Kim, P.; SøGaard, O.S.; Tolstrup, M.; Wong, J.K.; Yukl, S.A. Characterization of the HIV-1 transcription profile after romidepsin administration in ART-suppressed individuals. AIDS 2019, 33, 425-431. [CrossRef] [PubMed]

284. Lehrman, G.; Hogue, I.B.; Palmer, S.; Jennings, C.; Spina, C.A.; Wiegand, A.; Landay, A.L.; Coombs, R.W.; Richman, D.D.; Mellors, J.W.; et al. Depletion of latent HIV-1 infection in vivo: A proof-of-concept study. Lancet 2005, 366, 549-555. [CrossRef]

285. Archin, N.M.; Espeseth, A.; Parker, D.; Cheema, M.; Hazuda, D.; Margolis, D.M. Expression of latent HIV induced by the potent HDAC inhibitor suberoylanilide hydroxamic acid. AIDS Res. Hum. Retrovir. 2009, 25, 207-212. [CrossRef] [PubMed]

286. Wei, D.G.; Chiang, V.; Fyne, E.; Balakrishnan, M.; Barnes, T.; Graupe, M.; Hesselgesser, J.; Irrinki, A.; Murry, J.P.; Stepan, G.; et al. Histone deacetylase inhibitor romidepsin induces HIV expression in CD4 $\mathrm{T}$ cells from patients on suppressive antiretroviral therapy at concentrations achieved by clinical dosing. PLoS Pathog. 2014, 10, e1004071. [CrossRef] [PubMed]

287. Kulkosky, J.; Culnan, D.M.; Roman, J.; Dornadula, G.; Schnell, M.; Boyd, M.R.; Pomerantz, R.J. Prostratin: Activation of latent HIV-1 expression suggests a potential inductive adjuvant therapy for HAART. Blood 2001, 98, 3006-3015. [CrossRef] [PubMed]

288. Imai, K.; Togami, H.; Okamoto, T. Involvement of histone H3 lysine 9 (H3K9) methyltransferase G9a in the maintenance of HIV-1 latency and its reactivation by BIX01294. J. Biol. Chem. 2010, 285, 16538-16545. [CrossRef]

289. Kessing, C.F.; Nixon, C.C.; Li, C.; Tsai, P.; Takata, H.; Mousseau, G.; Ho, P.T.; Honeycutt, J.B.; Fallahi, M.; Trautmann, L.; et al. In Vivo Suppression of HIV Rebound by Didehydro-Cortistatin A, a "Block-and-Lock"; Strategy for HIV-1 Treatment. Cell Rep. 2017, 21, 600-611. [CrossRef] [PubMed]

290. Cullen, B.R. Does HIV-1 Tat induce a change in viral initiation rights? Cell 1993, 73, 417-420. [CrossRef]

291. Mousseau, G.; Clementz, M.A.; Bakeman, W.N.; Nagarsheth, N.; Cameron, M.; Shi, J.; Baran, P.; Fromentin, R.; Chomont, N.; Valente, S.T. An analog of the natural steroidal alkaloid cortistatin A potently suppresses Tat-dependent HIV transcription. Cell Host Microbe 2012, 12, 97-108. [CrossRef] [PubMed]

292. Mediouni, S.; Chinthalapudi, K.; Ekka, M.K.; Usui, I.; Jablonski, J.A.; Clementz, M.A.; Mousseau, G.; Nowak, J.; Macherla, V.R.; Beverage, J.N.; et al. Didehydro-Cortistatin A Inhibits HIV-1 by Specifically Binding to the Unstructured Basic Region of Tat. MBio 2019, 10, e02662-18. [CrossRef]

293. Mousseau, G.; Kessing, C.F.; Fromentin, R.; Trautmann, L.; Chomont, N.; Valente, S.T. The Tat Inhibitor Didehydro-Cortistatin A Prevents HIV-1 Reactivation from Latency. MBio 2015, 6, e00465. [CrossRef]

294. Wagschal, A.; Rousset, E.; Basavarajaiah, P.; Contreras, X.; Harwig, A.; Laurent-Chabalier, S.; Nakamura, M.; Chen, X.; Zhang, K.; Meziane, O.; et al. Microprocessor, Setx, Xrn2, and Rrp6 co-operate to induce premature termination of transcription by RNAPII. Cell 2012, 150, 1147-1157. [CrossRef]

295. Contreras, X.; Salifou, K.; Sanchez, G.; Helsmoortel, M.; Beyne, E.; Bluy, L.; Pelletier, S.; Rousset, E.; Rouquier, S.; Kiernan, R. Nuclear RNA surveillance complexes silence HIV-1 transcription. PLoS Pathog. 2018, 14, e1006950. [CrossRef] [PubMed] 
296. Campos, N.; Myburgh, R.; Garcel, A.; Vautrin, A.; Lapasset, L.; Nadal, E.S.; Mahuteau-Betzer, F.; Najman, R.; Fornarelli, P.; Tantale, K.; et al. Long lasting control of viral rebound with a new drug ABX464 targeting Rev mediated viral RNA biogenesis. Retrovirology 2015, 12, 30. [CrossRef]

297. Steens, J.-M.; Scherrer, D.; Gineste, P.; Barrett, P.N.; Khuanchai, S.; Winai, R.; Ruxrungtham, K.; Tazi, J.; Murphy, R.; Ehrlich, H. Safety, Pharmacokinetics, and Antiviral Activity of a Novel HIV Antiviral, ABX464, in Treatment-Naive HIV-Infected Subjects in a Phase 2 Randomized, Controlled Study. Antimicrob. Agents Chemother. 2017, 61, e00545-17. [CrossRef]

298. Vautrin, A.; Manchon, L.; Garcel, A.; Campos, N.; Lapasset, L.; Laaref, A.M.; Bruno, R.; Gislard, M.; Dubois, E.; Scherrer, D.; et al. Both anti-inflammatory and antiviral properties of novel drug candidate ABX464 are mediated by modulation of RNA splicing. Sci. Rep. 2019, 9, 792. [CrossRef] [PubMed]

299. Andersen, R.J.; Ntie-Kang, F.; Tietjen, I. Natural product-derived compounds in HIV suppression, remission, and eradication strategies. Antiviral Res. 2018, 158, 63-77. [CrossRef] [PubMed]

300. Jean, M.J.; Hayashi, T.; Huang, H.; Brennan, J.; Simpson, S.; Purmal, A.; Gurova, K.; Keefer, M.C.; Kobie, J.J.; Santoso, N.G.; et al. Curaxin CBL0100 Blocks HIV-1 Replication and Reactivation through Inhibition of Viral Transcriptional Elongation. Front. Microbiol. 2017, 8, 2007. [CrossRef]

301. Hayashi, T.; Jean, M.; Huang, H.; Simpson, S.; Santoso, N.G.; Zhu, J. Screening of an FDA-approved compound library identifies levosimendan as a novel anti-HIV-1 agent that inhibits viral transcription. Antiviral Res. 2017, 146, 76-85. [CrossRef] [PubMed]

302. Méndez, C.; Ledger, S.; Petoumenos, K.; Ahlenstiel, C.; Kelleher, A.D. RNA-induced epigenetic silencing inhibits HIV-1 reactivation from latency. Retrovirology 2018, 15, 67. [CrossRef]

303. Leoz, M.; Kukanja, P.; Luo, Z.; Huang, F.; Cary, D.C.; Peterlin, B.M.; Fujinaga, K. HEXIM1-Tat chimera inhibits HIV-1 replication. PLoS Pathog. 2018, 14, e1007402. [CrossRef]

304. Rutsaert, S.; Steens, J.-M.; Gineste, P.; Cole, B.; Kint, S.; Barrett, P.N.; Tazi, J.; Scherrer, D.; Ehrlich, H.J.; Vandekerckhove, L. Safety, tolerability and impact on viral reservoirs of the addition to antiretroviral therapy of ABX464, an investigational antiviral drug, in individuals living with HIV-1: A Phase IIa randomised controlled study. J. Virus Erad. 2019, 5, 10-22.

305. Turner, L.S.; Tsygankov, A.Y.; Henderson, E.E. StpC-based gene therapy targeting latent reservoirs of HIV-1. Antiviral Res. 2006, 72, 233-241. [CrossRef] [PubMed]

306. Ranganath, N.; Sandstrom, T.S.; Burke Schinkel, S.C.; Côté, S.C.; Angel, J.B. The Oncolytic Virus MG1 Targets and Eliminates Cells Latently Infected With HIV-1: Implications for an HIV Cure. J. Infect. Dis. 2018, 217, 721-730. [CrossRef]

307. Pache, L.; Dutra, M.S.; Spivak, A.M.; Marlett, J.M.; Murry, J.P.; Hwang, Y.; Maestre, A.M.; Manganaro, L.; Vamos, M.; Teriete, P.; et al. BIRC2/cIAP1 Is a Negative Regulator of HIV-1 Transcription and Can Be Targeted by Smac Mimetics to Promote Reversal of Viral Latency. Cell Host Microbe 2015, 18, 345-353. [CrossRef] [PubMed]

308. Mujib, S.; Saiyed, A.; Fadel, S.; Bozorgzad, A.; Aidarus, N.; Yue, F.Y.; Benko, E.; Kovacs, C.; Emert-Sedlak, L.A.; Smithgall, T.E.; et al. Pharmacologic HIV-1 Nef blockade promotes CD8 T cell-mediated elimination of latently HIV-1-infected cells in vitro. JCI Insight 2017, 2, 93684. [CrossRef] [PubMed]

309. Reinhard, R.J. Managing Expectations of an HIV Cure: What Should We Expect? AIDS Res. Hum. Retrovir. 2018, 34, 1. [CrossRef] [PubMed]

310. Lieberman, P.M. Epigenetics and Genetics of Viral Latency. Cell Host Microbe 2016, 19, 619-628. [CrossRef]

311. Salgame, P.; Geadas, C.; Collins, L.; Jones-López, E.; Ellner, J.J. Latent tuberculosis infection-Revisiting and revising concepts. Tuberculosis 2015, 95, 373-384. [CrossRef]

(C) 2019 by the authors. Licensee MDPI, Basel, Switzerland. This article is an open access article distributed under the terms and conditions of the Creative Commons Attribution (CC BY) license (http://creativecommons.org/licenses/by/4.0/). 